\title{
The fish fauna of the Dynów Marl Member (Menilite Formation, Poland): paleoenvironment and paleobiogeography of the early Oligocene Paratethys
}

\author{
MatgorZATA BiEŃKOWSKA-WASILUK
}

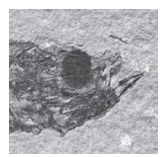

\begin{abstract}
The Dynów Marl Member of the Menilite Formation in Poland is one of the most significant lithostratigraphic units containing fauna of the early Oligocene Paratethys. The fish fauna from this member is presented, including three shark taxa and eight teleost taxa. The connection between the Upper Rhine Graben and the Central Paratethys in the calcareous nannoplankton zone NP23 (about 30-32 Ma ago) is consistent with the occurrence of the teleost Anenchelum glarisianum and the shark Keasius parvus. The presence of the teleosts Scopeloides glarisianus, Vinciguerria obscura and Oligophus moravicus confirms the connections between the Eastern and Central Paratethys. The distribution of the ichthyofauna supports the existence of a marine connection between the North Sea, the Upper Rhine Graben, the northwestern Tethys, and the Central and Eastern Paratethys during the early Oligocene. The fish assemblage shows a high percentage of fishes, whose extant relatives are living in the depth interval between 0 and $500 \mathrm{~m}$. The presence of Gonostomatidae, Phosichthyidae and Myctophidae indicates normal salinity in the deep pelagic life zones. The fish fauna show distinctly Paratethyan affinities. - Key words: Teleostei, Elasmobranchii, Rupelian, Outer Carpathians.
\end{abstract}

\begin{abstract}
Bieńkowska-Wasiluk, M. 2021. The fish fauna of the Dynów Marl Member (Menilite Formation, Poland): paleoenvironment and paleobiogeography of the early Oligocene Paratethys. Bulletin of Geosciences 96(4), 493-511 ( 7 figures, 1 table, 3 electronic appendices). Czech Geological Survey, Prague. ISSN 1214-1119. Manuscript received September 28, 2020; accepted in revised form June 3, 2021; published online July 18, 2021; issued October 1, 2021.
\end{abstract}

Matgorzata Bieńkowska-Wasiluk, Faculty of Geology, University of Warsaw, Żwirki i Wigury 93, 02-089 Warsaw, Poland;m.wasiluk@uw.edu.pl

Origin of the Paratethys is defined by the presence of endemic bivalve fauna inhabiting newly formed semi-closed basin, correlated with the early Oligocene nannoplankton zone NP23 (Martini 1971, Studencka et al. 2016). The isolation of the basin was noticeably influenced by the global cooling during the Cenozoic and the convergence between the European and Adriatic (African) plates (Rusu 1977, 1988; Báldi 1989; Kováč et al. 1994, 1997, 2016, 2017; Rögl 1998, 1999; Meulenkamp et al. 2000; Steininger \& Wessely 2000; Popov et al. 2002; Schulz et al. 2004). Many authors have correlated the origin of the Paratethys with the Eocene-Oligocene boundary and particular factors indicating the isolation of the basin (Schulz et al. 2005, Sachsenhofer et al. 2017).

The deposition period of the Dynów Marl Member of the Menilite Formation in Poland covers a part of NP23, which was a significant period of the early Paratethys. The diverse assemblage of fish provides an essential insight into the paleoenvironment of the Central Paratethys and is of particular importance, because it contains fauna with a wide distribution, from the Upper Rhine Graben to the Eastern Paratethys. Lists of the fish fauna from this member have been presented by Kotlarczyk et al. (2006), and Bieńkowska-Wasiluk (2010). Previous descriptions of the fishes of the member have been restricted to material referring to Alopiidae and Cetorhinidae (BieńkowskaWasiluk \& Radwanski 2009) as well as Gonostomatidae (Prikryl et al. 2012). New specimens of the fish fauna from this member are presented in this study, along with their paleoenvironmental, and paleogeographic implications.

\section{Geological setting}

The Dynów Marl Member is a marine sequence consisting of an alternation of bituminous, brown to light beige marlstones, brown and black cherts, shales and sandstones. It overlies bituminous black to brown cherts and shales of the Kotów Chert Member, and is overlain by bituminous brown to black shales and sandstones of the Rudawka Tractionite Member. The Dynów Marl Member occurs in most of the main tectonic units of the Outer Carpathians 


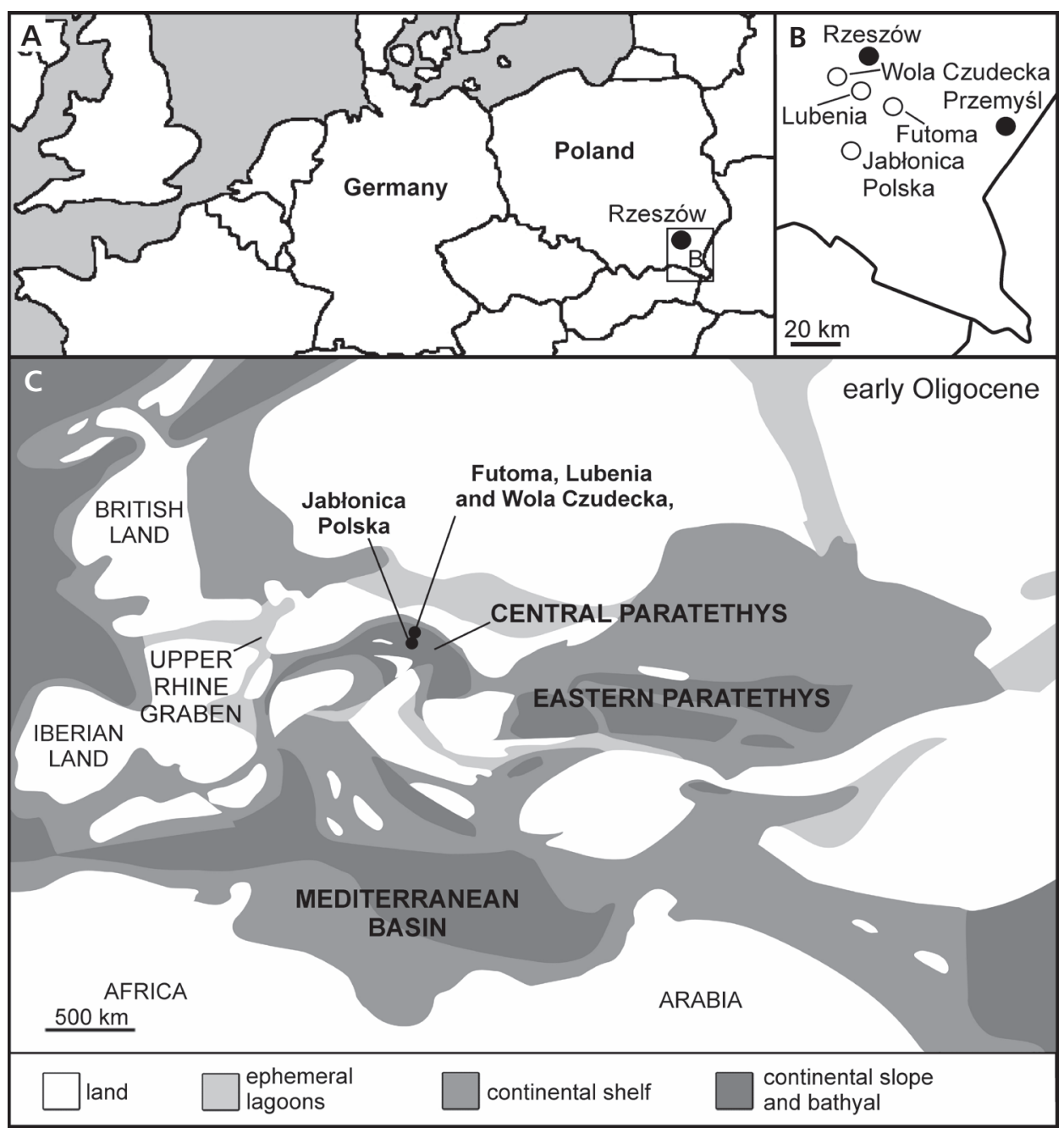

Figure 1. Location maps of the Oligocene fossil sites (Futoma, Lubenia, Wola Czudecka, and Jabłonica Polska). A - map of Europe showing the area with the localities near Rzeszów city in the Outer Carpathians, Poland. $\mathrm{B}$ - map with the localities of the Dynów Marl Member. C - early Oligocene (Rupelian) paleogeography (adopted from Popov et al. 2002) with the location of the fossil sites. in Poland (see Kotlarczyk et al. 2006). The sediments of the Dynów Marl Member are rich in organic matter, barren of macrobenthos, but rich in fish.

The specimens were found in four different localities (Fig. 1A, B, electronic appendix 1). Three of them are in the Skole Nappe of the Outer Carpathians and are located near the villages of Futoma, Lubenia, and Wola Czudecka. The Jabłonica Polska locality is in the Silesian Nappe. The Futoma (Błażowa) quarry is located $30 \mathrm{~km}$ southeast of Rzeszów city. The Lubenia and the Wola Czudecka localities are situated $20 \mathrm{~km}$ southwest of Rzeszów city (Bieńkowska-Wasiluk 2010). The Jabłonica Polska locality is $50 \mathrm{~km}$ south of Rzeszów city, and has two outcrops (Studencka et al. 2016). The Dynów Marl Member has a thickness ranging from $6 \mathrm{~m}$ in Jabłonica Polska to $30 \mathrm{~m}$ at Futoma locality.

The Dynów Marl Member is correlated with the nannoplankton zone NP23 of Martini (1971) and the ichthyofaunal zone IPM1 (Kotlarczyk et al. 2006), and is dated to the early Oligocene, $c a$. $32 \mathrm{Ma}$.
The deposits of the Dynów Marl Member document the environment of the northwestern part of the Carpathian Basin, and the northern Central Paratethys (Fig. 1C). The deposits accumulated in a variably deep basin with anoxic waters at and above the sea floor, with oxygenated deep waters, the activity of submarine fans, the activity of bottom currents, in some cases with debris flows and deposition from low-concentration turbidity currents as well as pelagic sedimentation and the blooms of coccolithophores (Krhovský 1981, Kotlarczyk et al. 2006, Bieńkowska-Wasiluk 2010, Górniak 2011, Kotlarczyk \& Uchman 2012). Interpretations of the depositional system of the Menilite Formation, which comprises the Dynów Marl Member, are widely variable. Based on sedimentological analyses, paleontological analyses including foraminifera and fishes, alongside other considerations; deposition on the continental slope, submarine ridges and basin floor (e.g., Książkiewicz 1975, Olszewska 1985, Kotlarczyk et al. 2006, Szydło et al. 2014, Siemińska et al. 2020), and locally on the shelf is assumed (e.g., Olszewska 
1985, Dziadzio et al. 2016, Olszewska \& Szydło 2017, Suchocka et al. 2019). Based on sedimentological observations, Dziadzio (2018) has assumed a locally coastal environment. Jankowski (2015) has considered for some deposits (e.g., kliwa facies, diatomites) shelf environment, even with shallow sea setting.

The Dynów Marl Member is correlated with the Dynów Marlstone of the Menilitic Formation in the Central Paratethys (Czech Republic localities) and the Bituminous Marls in the southeastern Central Paratethys (Romanian localities) (see Krhovský et al. 1992, Baciu et al. 2016, Studencka et al. 2016). Sachsenhofer et al. (2017) has correlated this unit with the Polbian ('Ostracoda') Bed in the Eastern Paratehys (Russian localities, North Caucasus). The Dynów Marl Member is correlated herein with the Hochberg Member of the Bodenheim Formation (see Maxwell et al. 2016) in the Upper Rhine Graben (Western Paratethys) based on its nannoplankton record.

\section{Materials and methods}

The described material was collected from 1995 to 2018 . The collection of fossil fishes at the Faculty of Geology, University of Warsaw comprises 67 specimens (some of them with counterparts, designated with ' $a-b$ ' in the collection numbers), and at the Muzeum Skamieniałości i Minerałów, Dubiecko, which comprises six specimens. The specimens were studied under a stereo microscope Nikon SMZ1000 at the Scanning Electron Microscope and Microanalysis Laboratory, Faculty of Geology, Warsaw University.

The sizes of the fishes were measured as standard length (SL), which is the length of a specimen measured from the anterior tip of the snout to the posterior margin of the hypurals.

Institutional abbreviations: MWGUW - Stanisław Józef Thugutt Geological Museum, Faculty of Geology, University of Warsaw; MSMD - Muzeum Skamieniałości i Minerałów, Dubiecko, Poland.

\section{Systematic Paleontology}

Class Chondrichthyes Huxley, 1880

Subclass Euselachii Hay, 1902

Infraclass Elasmobranchii Bonaparte, 1838

Order Lamniformes Berg, 1958

Family Alopiidae Bonaparte, 1838

\section{Genus Alopias Rafinesque, 1810}

\section{Alopias aff. superciliosus Lowe, 1841}

Figure 2A
Material. - MWGUW ZI/57/143/a-b, ZI/57/145/a-b, Futoma; MWGUW ZI/57/007-009, Wola Czudecka.

Description. - The species is represented by four teeth of the lower jaw embedded in a marly matrix, exhibiting their labial view. A single tooth of the lower jaw, which is embedded in the marly matrix, is visible in lingual view. The teeth have a slender, acute and distally inclined cusp with a broad base. The mesial cutting edge is rather straight, whereas the distal one is concave, mainly at its base. Both cutting edges are sharp. The labial crown face is almost flat, whereas the lingual face is convex. Both faces are devoid of any ornamentation. The root has asymmetrical, well-separated and long lobes. The mesial lobe is longer than the distal one. The extremites of the lobes are rounded. The base of the crown extends laterally on the lobes by strong enameled shoulders. More details are available in Bieńkowska-Wasiluk \& Radwanski (2009, as Alopias sp.).

Remarks. - The morphology of the examined specimens is consistent with that of $A$. superciliosus and matches perfectly with that of $A$. aff. superciliosus reported from the Oligocene (Cappetta et al. 2016). The specimens of $A$. aff. superciliosus from the Menilite Formation have been described by Bieńkowska-Wasiluk \& Radwanski (2009) in Poland and Gregorová (2011) and Cappetta et al. (2016) in the Czech Republic.

Ecology of related extant forms: Alopias superciliosus (bigeye thresher shark) lives in coastal waters over the continental shelves, in the epipelagic zone far from the land; it is also caught near the bottom in deep water on the continental slopes, sometimes close to inshore in shallow waters. Its distribution in the water column ranges from 0 to $500 \mathrm{~m}$, but it mostly cruises in depths below $100 \mathrm{~m}$. It inhabits almost circumglobally tropical and warm temperate waters, where it feeds on pelagic fishes (Compagno 2002).

Family Cetorhinidae Gill, 1862

\section{Genus Keasius Welton, 2013}

\section{Keasius parvus (Leriche, 1908)}

Figure 2B

Material. - MWGUW ZI/57/101-102, ZI/57/141, ZI/57/142/1-3, Futoma; MWGUW ZI/57/140/a-b, Jabłonica Polska; MWGUW ZI/57/010-012, ZI/57/204, Wola Czudecka.

Description. - The species is represented by ten complete and one fragmentary isolated gill rakers (branchiospines). Each gill raker has the shape of a narrow and elongated 

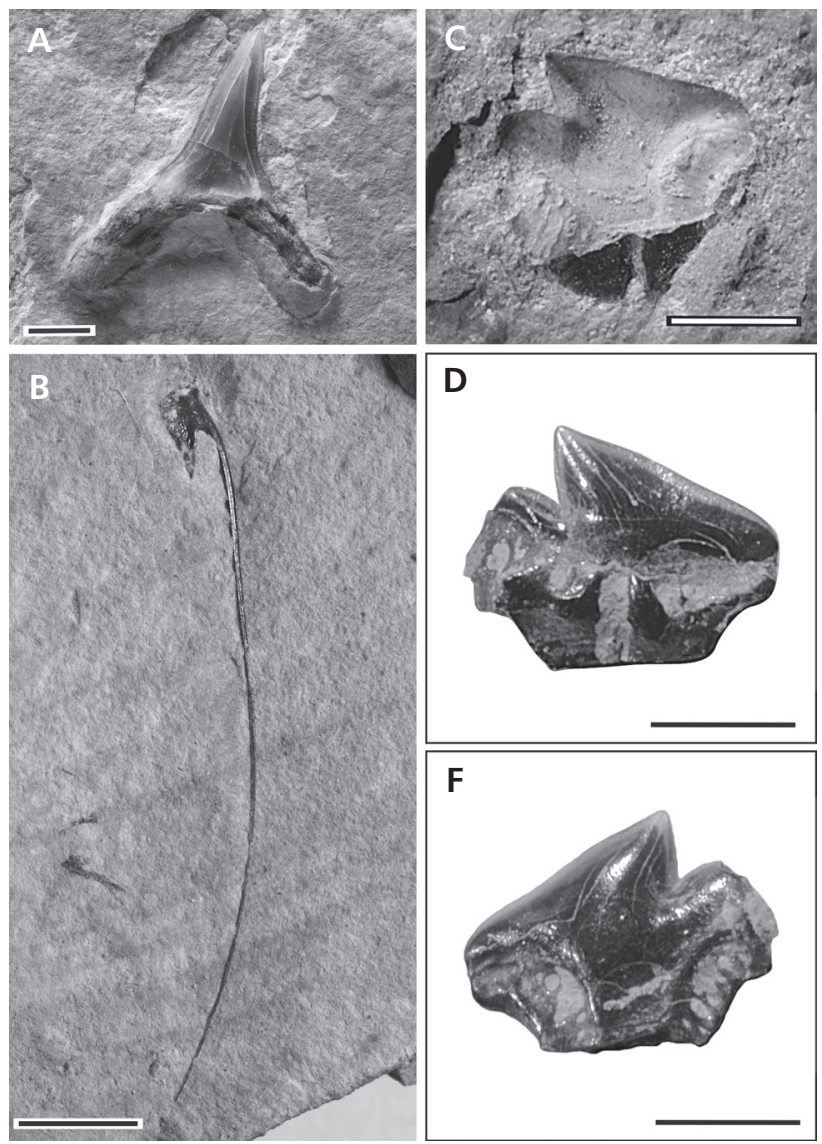

D
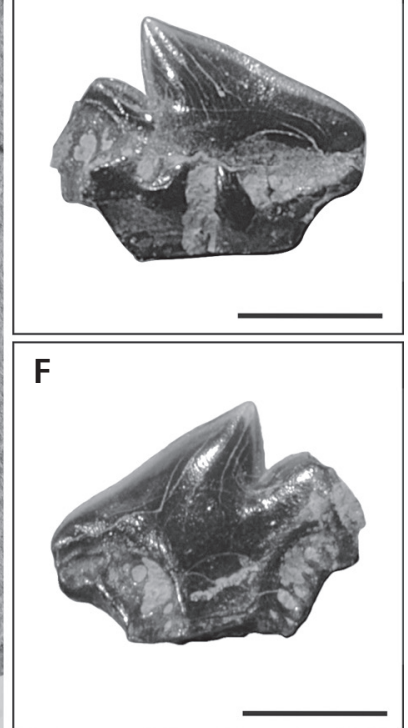

Figure 2. Sharks from the Dynów Marl Member, the Outer Carpathians, Poland. - A - lower tooth of Alopias aff. superciliosus in labial view, MWGUW ZI/57/145/a. • B - gill raker of Keasius parvus, MWGUW ZI/57/141. • C-E - a lower tooth of Centrophoridae indet., MWGUW $\mathrm{ZI} / 57 / 139 / \mathrm{a}-\mathrm{b}$; C - imprint of the labial face with part of root preserved visible in lingual view; D - lingual view; E - labial view. Scale bars equal $2 \mathrm{~mm}(\mathrm{~A}, \mathrm{C}-\mathrm{E})$ and $5 \mathrm{~mm}(\mathrm{~B})$.

stick (filament) with a laterally flattened base, and reaches a length of up to $30 \mathrm{~mm}$. The filament base is relatively narrow, moderately long, and strongly to moderately curved (terms follow Welton 2013). The medial process is triangular, moderately long and narrow. The bight is intermediate and ranges from subangular to rounded.

Remarks. - The morphology of the examined gill rakers is fully consistent with that of $K$. parvus reported by Welton (2013). The species is known from the Oligocene to the Middle Miocene, and in the past was usually described as Cetorhinus sp. or C. parvus. Welton (2013) assigned this species to the new genus Keasius. Detailed descriptions of specimens of Keasius parvus from the Menilite Formation have been given by Bieńkowska-Wasiluk \& Radwanski (2009, as Cetorhinus sp.) in Poland and by Gregorová (2011) and Cappetta et al. (2016) in the Czech Republic.
Ecology of related extant forms: The nearest relative to Keasius parvus is the recent Cetorhinus maximus. It is a coastal-pelagic and semioceanic filter feeder of boreal towarm-temperatewaters(Compagno2002).Itoccursmainly in shallow coastal and epipelagic waters; its distribution in the water column ranges from 0 to $4000 \mathrm{~m}$ (Compagno 2002).

Order Squaliformes Goodrich, 1909

Family Centrophoridae Bleeker, 1859

\section{Centrophoridae gen. et sp. indet.}

Figure 2C-E

Material. - MWGUW ZI/57/139/a-b, Jabłonica Polska.

Description. - The family is represented by a single tooth of the lower jaw. This tooth is labio-lingually compressed, blade-like, with a vertical basal groove on its lingual root, and with a broad cusp, which is directed distally. A distinct convex distal blade is present, which is separated from the principal cusp by a notch. The infundibulum is not preserved. There is no serration on the cusp and the blade, which indicates a juvenile individual (White et al. 2013).

Remarks. - The examined specimen shows a combination of diagnostic features typical of the Centrophoridae reported by White et al. (2013). The tooth is similar to Centrophorus and Deania.

Ecology of related extant forms: The extant Centrophorus is commonly found along the outer continental shelves and upper slopes, sustaining at $4000 \mathrm{~m}$ depth, but usually bottom-dwelling at depths between 200 and $800 \mathrm{~m}$ (Compagno et al. 2005). The extant Deania is commonly found either on or near the bottom, or well above it at the outer continental and insular shelves and upper slopes, in depths between 70 and $1790 \mathrm{~m}$ (Compagno 1984).

Class Osteichthyes Huxley, 1880

Subclass Actinopterygii Klein, 1885

Division Teleostei Müller, 1845

Order Clupeiformes Bleeker, 1859

Family Clupeidae Cuvier, 1817

\section{Clupeidae gen. et sp. indet.}

Figure $3 \mathrm{~A}$

Material. - MWGUW ZI/57/148-149, Jabłonica Polska.

Description. - The family is represented by two cycloid scales, typical clupeid forms with transversal striae.

Remarks. - The scales described here match perfectly with those reported from the Oligocene by Szymczyk (1978) and those of recent fishes by Bräger \& Moritz (2016). 

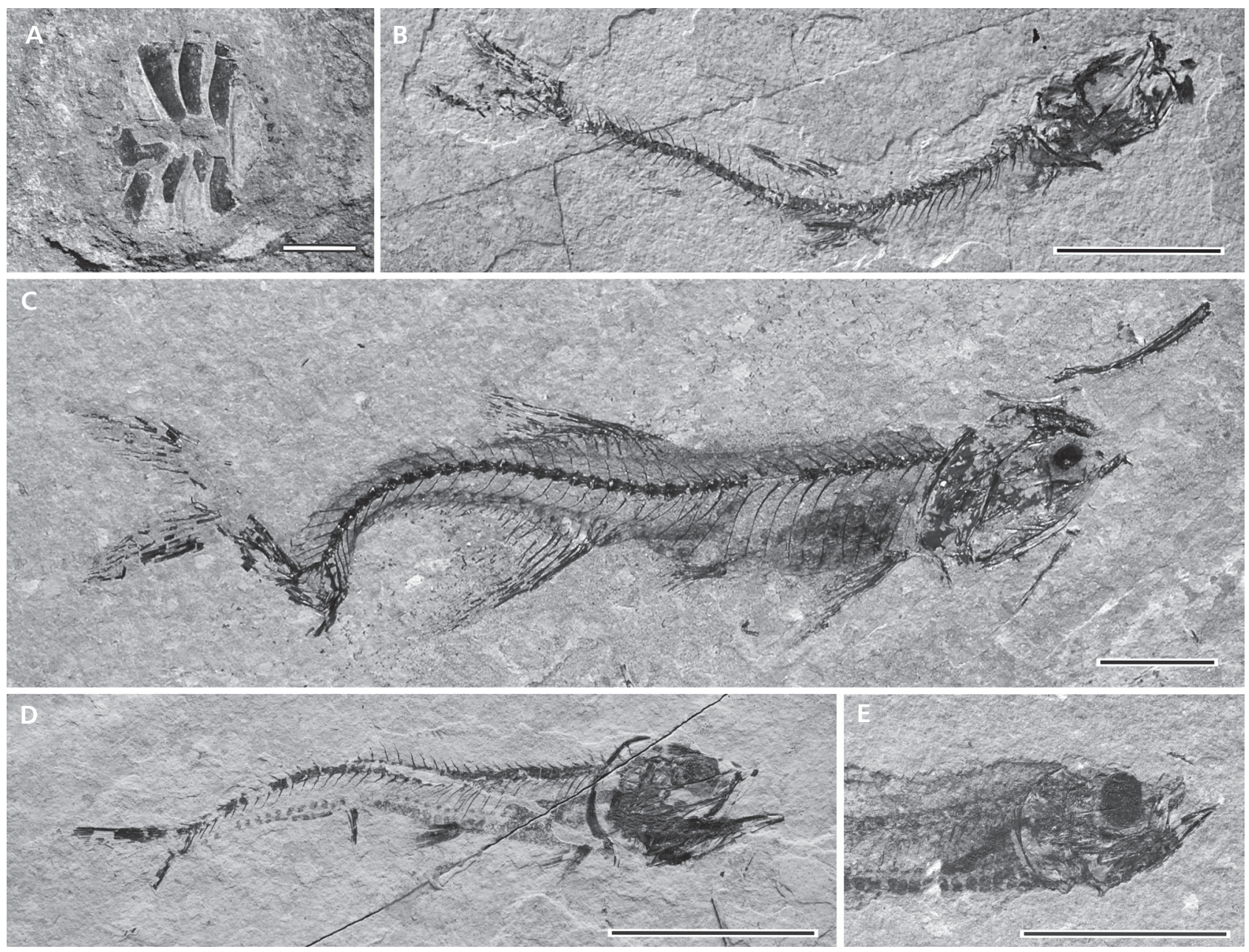

Figure 3. Teleosts from the Dynów Marl Member, Outer Carpathians, Poland: Clupeiformes, Argentiniformes, and Stomiiformes. • A - cycloid scale of Clupeidae indet., anterior field oriented left, MWGUW ZI/57/148. • B - 'Glossanodon' musceli, MWGUW ZI/57/156. • C - Scopeloides glarisianus, MWGUW ZI/57/094/a. • D, E - Vinciguerria obscura, MWGUW ZI/57/127/a (D), MWGUW ZI/57/147/2/a (E). Scale bars equal $2 \mathrm{~mm}$ (A) and $10 \mathrm{~mm}(\mathrm{~B}-\mathrm{E})$.

Ecology of related extant forms: Clupeids are typically marine coastal, oceanodromous fihes; some enter brackish or fresh water. Their distribution in the water column mostly ranges between 0 and $200 \mathrm{~m}$ (Froese \& Pauly 2021).

Order Argentiniformes Bertelsen, 1958

Family ?Argentinidae Bonaparte, 1846

\section{Genus Glossanodon Guichenot, 1867}

'Glossanodon' musceli (Paucă, 1929)

Figure 3B

Material. - MWGUW ZI/57/144/a-b, ZI/57/147/1/a-b, ZI/57/199/a-b, ZI/57/200/a-b, Futoma; MWGUW ZI/57/ 202, Lubenia; MWGUW ZI/57/150/1/a-b, ZI/57/150/2/a, ZI/57/151/a-b, ZI/57/152-156, Wola Czudecka.
Description. - The species is represented by nine complete and four incomplete skeletons. It is a small-sized fish (SL $42-54 \mathrm{~mm}$ ) with an elongated, somewhat laterally compressed body. The small terminal mouth ends in front of the orbit; there are no teeth on the premaxilla and maxilla. The maxilla is slightly bent and has a flattened posterior projection, rounded antero-ventrally. There are 45-52 vertebrae, of which 25-29 are abdominal and 20-25 are caudal. The fins are without spines. A single dorsal fin with 10-13 soft rays is almost located above the midpoint of the body. The anal fin originates opposite and posterior to the dorsal fin (starts about four to eight vertebrae posterior to the last ray of the dorsal fin), and is composed of 12-13 (or slightly more) rays. The pectoral fin is situated near the ventrolateral part of the body flank and has 16-17 (or slightly more) rays. The pelvic fins originate beneath or slightly anterior to the dorsal fin. They are composed of about 10 rays. The caudal fin is deeply forked. 
Remarks. - The specimens have the same morphology, diagnostic features and meristics as those of ' $G$ '. musceli described by Jerzmańska (1967), Gregorová (2011), and Prrikryl et al. (2016). The material described here shows the diagnostic characters (see Jerzmańska 1967), i.e., maxilla has a flattened posterior projection, rounded antero-ventrally, number of vertebrae, position of dorsal, anal, and pelvic fins, number of rays in pelvic fin. The species ' $G$ '. musceli has been described by Paucă (1929, 1934), Daniltshenko (1960), Jerzmańska (1967), Přikryl (2013), and Přikryl et al. (2016). Jerzmańska (1967) claimed that it belongs to the Argentinidae. Prokofiev (2005a) erected a new genus Austromallotus in the family Osmeridae and ascribed the specimens from the Oligocene of the Caucasus to the species Austromallotus musceli. He suggested that the material described by Jerzmańska (1967) also belongs to A. musceli. Přikryl (2013) did not recognize $A$. musceli as a synonym of the species from the Carpathians. The important morphological features that can be used to discriminate between Argentinidae and Osmeridae are: (1) presence of a notch on the dorsal edge of the opercle; (2) strongly shortened and depressed neural spines on the anterior abdominal vertebrae; and (3) presence or absence of contact between the $1^{\text {st }}$ and $2^{\text {nd }}$ infraorbitals (Prokofiev 2005a). In the studied material, some specimens have strongly shortened and depressed neural spines on the anterior abdominal vertebrae, whereas others have elongated spines that are slightly inclined more posteriorly. The presence of the opercular notch and the arrangement of the $1^{\text {st }}$ and $2^{\text {nd }}$ infraorbitals cannot be verified because of the insufficient preservation of the investigated materials. Therefore, the traditional classification within the genus 'Glossanodon' is accepted here. More precise identification of the fishes from the studied area must wait until skeletons with preserved diagnostic characters are discovered.

Ecology of related extant forms: The recent Glossanodon occurs on the outer continental shelf and the upper slope, mostly near the bottom. Its distribution in the water column ranges between 70 and $1000 \mathrm{~m}$ (Froese \& Pauly 2021).

Order Stomiiformes sensu Harold \& Weitzman, 1996

Family Gonostomatidae Gill, 1893

\section{Genus Scopeloides Wettstein, 1886}

\section{Scopeloides glarisianus (Agassiz, 1844)}

Figure 3C

Material. - MWGUW ZI/57/094/a-b, ZI/57/112/a-b, ZI/57/132, ZI/57/188, ZI/57/191, ZI/57/197, ZI/57/201, Futoma; MWGUW ZI/57/130/a-b, MWGUW ZI/57/131, Wola Czudecka.
Description. - This species is represented by six complete and three incomplete skeletons. It is a medium-sized fish (SL 58-108 $\mathrm{mm}$ ) with a moderately elongated body; both the head and the body are laterally compressed. The maximum depth of the body is 5.66 .8 in SL. The orbit is small, the mouth is large and terminal, and the quadrate joint with the mandible is clearly located posterior to the orbit. Teeth are present on the premaxilla, the maxilla, and the dentary. They are conical in shape and of two different lengths: Some are elongate and fang-like, with interspaces occupied by small needle-like teeth. There are 39-41 vertebrae, of which 18-19 are abdominal and 21-22 are caudal. There is a single dorsal fin with 14-15 soft rays, which is located above and slightly posterior to the midpoint of the body. The pectoral fin inserts close to the ventrolateral margin of the body flank and it has 11-12 rays. The anal fin inserts opposite and slightly posterior to the dorsal fin. It consists of about 25 rays. The pelvic fins are located in front of the dorsal fin, and have 8-9 rays. The caudal fin is deeply forked. One row of photophores (of the series PV, VAV, and AC) is poorly preserved close to the ventrolateral margin of the body flank.

Remarks. - The material described here shows the diagnostic characters of Scopeloides (see Prokofiev 2005b): frontalia with cancellate-cristate sculpture, number of vertebrae, number of rays in dorsal and anal fins, position of anal and pelvic fins, and anterior rays of the dorsal and anal fins distinctly larger than the posterior rays. The specimens have the same morphology and numbers of dorsal, pectoral and pelvic fin rays as those of $S$. glarisianus described by Gregorová $(1997,2011)$ and Grădianu et al. (2017). The number of vertebrae (3941) in the material is the same as that reported by Grădianu et al. (2017) and slightly greater as that given by Gregorová $(1997,2011 ; 38-39)$ and overlaps with data from Prokofiev (2005b; 37-40). The number of anal fin rays in the specimens described is smaller (25) than that reported by Gregorová $(1997,2011 ; 27)$ and Grădianu et al. (2017; 28-29), because of its insufficient state of preservation. Detailed descriptions of specimens of S. glarisianus from the Menilite Formation have been given by Gregorová (1997, 2011), Prokofiev (2005b), and Grădianu et al. (2017).

Ecology of related extant forms: The recent Gonostoma is mesopelagic and bathypelagic. Its distribution in the water column ranges between 50 and $1350 \mathrm{~m}$, but mostly between 300 and $700 \mathrm{~m}$ by day and $50-200 \mathrm{~m}$ by night. It is found almost circumglobally in tropical and subtropical waters (Froese \& Pauly 2021).

Family Phosichthyidae Weitzman, 1974

Genus Vinciguerria Prokofiev, 2002 
Vinciguerria obscura (Daniltshenko, 1946)

Figure 3D, E

Material. - MWGUW ZI/57/126/a-b, ZI/57/147/2/ a-b, ZI/57/189/a-b, ZI/57/192/a-b, ZI/57/193, ZI/57/195/1, ZI/57/195/2/a-b, ZI/57/196, ZI/57/198, Futoma; MWGUW ZI/57/127/a-b, ZI/57/202, Lubenia; MWGUW ZI/57/076, ZI/57/128/a-b, ZI/57/129, Wola Czudecka.

Description. - This species is represented by seven complete and seven incomplete skeletons. It is a small-sized fish (SL 25-39 mm) with an elongated body; the head and the body are laterally compressed. The orbit is large. The mouth is large and terminal; the size of the teeth ranges from small to large $(0.1-0.5 \mathrm{~mm})$, but they are not highly elongate and fang-like. There are 39-43 vertebrae, of which 21-24 are abdominal and 17-19 are caudal. There is a single dorsal fin with slightly more than 10 soft rays, which is almost located above the midpoint of the body. The pectoral fin inserts near the ventrolateral margin of the body flank and has 10-11 rays. The anal fin has a moderately long base, and is located beneath and distinctly posterior to the dorsal fin. It is composed of slightly more than 15 rays. The pelvic fins insert anterior to the dorsal fin and have seven rays. The caudal fin is deeply forked. There are two ventrolateral rows of photophores on the body flank.

Remarks. - The combination of characters listed herein supports the attribution of the specimens to $V$. obscura (see Grădianu et al. 2020), including the position of the dorsal fin, and the maxilla bearing a series of small variably sized conical teeth. The examined specimens have the same morphology and similar meristics (number of vertebrae, and numbers of dorsal, anal, pelvic, and pectoral fin rays) as $V$. obscura, described in detail by Gregorová (2000, 2011), Prokofiev (2005b), and Grădianu et al. (2020).

Ecology of related extant forms: The recent Vinciguerria is mesopelagic and bathypelagic. Its distribution in the water column ranges from 50 to $5000 \mathrm{~m}$, but it is mostly found between 200 and $600 \mathrm{~m}$ by day and between 50 and $500 \mathrm{~m}$ by night. It inhabits almost circumglobally tropical and subtropical waters (Froese \& Pauly 2021).

Order Myctophiformes Regan, 1911

Family Myctophidae Gill, 1893

\section{Genus Oligophus Gregorová, 2004}

Oligophus moravicus (Paucă, 1931)

Figure 4A
Material. - MWGUW ZI/57/092, ZI/57/093/a-b, ZI/57/146, ZI/57/190/a-b, ZI/57/194/a-b, Futoma; MWGUW ZI/57/077/a-b, ZI/57/091/a-b, ZI/57/137, Wola Czudecka.

Description. - This species is represented by five complete and three incomplete skeletons. It is a smallsized fish (SL 29-61 mm) with an elongated body; the head and the body are laterally compressed. The large terminal mouth ends far behind (about one eye diameter) a vertical line through the posterior margin of the orbit. The premaxillaries and dentaries show bands of densely spaced small teeth. There are 35-37 vertebrae, of which 14-16 are abdominal and 21-22 are caudal. Fin spines are absent. There is a single dorsal fin with 12-14 soft rays; its origin is slightly anterior to a vertical line through the mid-point of the body. The anal fin originates opposite to the posterior margin of the dorsal fin base. It has 13-16 rays. The pectoral fin is high on the body flank and has 11-13 rays. The pelvic fins insert beneath the origin of the dorsal fin and have eight rays. The caudal fin is deeply forked. Distinct groups of photophores (i.e., PLO, PVO, Prc, VO series, abbreviations follow Prokofiev 2006) are to be noticed on the body flank. The scales are cycloid with radial fissures.

Remarks. - The examined specimens show diagnostic features typical of Oligophus (see Gregorová 2004, Prokofiev 2006), including: long jaws, extending about one eye diameter behind a vertical line through the posterior margin of the orbit; number of vertebrae; presence of one photophore of PLO series at the level of the pectoral fin base; two photophores of PVO series below the pectoral fin base; presence of three photophores of Prc series near the caudal fin; presence of five photophores (VO series) behind the pelvic fins and anterior to the anal fin. The morphology and the osteology of the material described are the same, and the meristics is similar (number of vertebrae, and numbers of dorsal, anal, and pelvic fin rays) as O. moravicus, described by Gregorová (2004) and Prokofiev (2006). Otoliths of the species (previously under the name Diaphus longirostris) were described by Brzobohatý \& Nolf (1995), Přikryl et al. (2017), and Brzobohatý \& Bubík (2019).

Ecology of related extant forms: Myctophidae are very common and occur in all oceans, from Arctic to Antarctic waters. Many undertake diurnal vertical migrations, their distribution in the water column ranges from the surface to depths exceeding $2000 \mathrm{~m}$. Many spend the night at depths between 30 and $100 \mathrm{~m}$ (Nafpaktitis 1984).

Order Gadiformes Goodrich, 1909, sensu Endo, 2002

Family Merlucciidae Gill, 1884 


\section{Genus Palaeogadus Rath, 1859}

\section{Palaeogadus sp.}

Figure 4B

Material. - MWGUW ZI/57/138, Jabłonica Polska.

Description. - This genus is represented by a single otolith, which is elongated and fusiform in outline. The size of this otolith exceeds $7 \mathrm{~mm}$; otolith length to otolith height is about 2.2. Its ventral rim is shallow and smooth. The dorsal rim is gently curved. The sulcus is located in the middle of the long axis of the otolith. The oval ostium is smaller than the oval cauda. The pseudocolliculum is absent. The otolith resembles those of $P$. germanus and P. rarus (see Bratishko \& Udovichenko 2013), both of which are known from otoliths and well-preserved skeletons from the Caucasus (Fedotov 1980). Unfortunately, the preservation of the present specimen does not allow assignment to a particular species.

Remarks. - The morphology of the examined otolith is similar to the otoliths of Palaeogadus reported by Bratishko \& Udovichenko (2013) and Brzobohatý \& Bubík (2019). The single otolith of Palaeogadus from the Dynów Marlstone of the Czech Republic has been described by Brzobohatý \& Bubík (2019).

Ecology of related extant forms: Merlucciidae inhabit the continental shelf and upper slope, but some also enter estuaries and/or very deep waters, exceeding $1000 \mathrm{~m}$ (Cohen et al. 1990).

Order Scombriformes Rafinesque, 1810

Family Euzaphlegidae Daniltshenko, 1960

\section{Genus Palimphyes Agassiz, 1844}

\section{Palimphyes sp.}

Figure 4C

Material. - MWGUW ZI/57/157/a-b, ZI/57/158/a-b, MSMD Ma-47, Ma-113, Futoma.

Description. - This species is represented by three complete and one incomplete skeleton. It is a mediumsized fish (SL 55-140 mm) with an elongated and fusiform body, which is moderately compressed laterally. The mouth is moderately large and located terminally. The teeth on the premaxilla and the dentary are moderately strong. There are 36-37 vertebrae, of which 15-16 are abdominal and 21 are caudal. There are two dorsal fins, of which the first is short and separated from the second by about four rayless pterygiophores. The first dorsal has eight or nine spines, the second has about 20 rays. The anal fin has more than 14 rays. The pectoral fin inserts high on the body flank and has about 10 rays. The pelvic fins are located beneath and slightly posterior to the latter. They have about five rays. The caudal fin is deeply forked. The scales are ctenoid.

Remarks. - The total number of rays of the anal fin was unclear in the investigated material, because of its insufficient state of preservation. About 14 rays were observed, but it is probablethat there were originally more. The described specimens show diagnostic features typical of Palimphyes (see Monsch \& Bannikov 2012), including number of vertebrae, dorsal fins not closely adjoined, separated by rayless pterygiophores. The meristic data (number of dorsal, anal, pelvic and pectoral fin rays) of the examined specimens are similar to those of Palimphyes, described by Gregorová (2011) and Monsch \& Bannikov (2012). The genus has been described in the Dynów Marlstone of the Czech Republic by Gregorová (2011).

Ecology of related extant forms: Palimphyes is an extinct genus of primitive scombriform fishes. Scombriforms are pelagic and marine (Carpenter et al. 1995, Collette et al. 2001). Their distribution in the water column ranges from 0 to more than 1000 (Froese \& Pauly 2021).

Family Trichiuridae Rafinesque, 1810

\section{Genus Anenchelum Blainville, 1818}

Anenchelum glarisianum Blainville, 1818

Figure 4D

Material. - MWGUW ZI/57/125, MSMD Ma-2/L, Ma-3, Ma-4/L, Ma-10, Futoma.

Description. - This species is represented by three complete and two incomplete skeletons. It is a predominantly large fish, up to about $1350 \mathrm{~mm}$ SL (Gregorová, 2010). The materials that were investigated herein had an SL of 300 to about $1200 \mathrm{~mm}$. The body is ribbon-like and remarkably elongate and laterally compressed. The mouth is large and terminal, the teeth are strong and usually fang-like in the anterior portions of the upper and lower jaws. The lower jaw articulation facet is located beneath the middle of the orbit or posterior to the latter. There are $115-117$ vertebrae, of which $35-40$ are abdominal and $77-82$ are caudal. There is a single dorsal fin, which extends almost along the complete length of the body. It has more than 89 rays. There are spines in the anterior part of the fin, which are shorter than the soft rays of the posterior part of the fin. The anal fin has more than 56 rays. The pectoral fins are large and have more than 

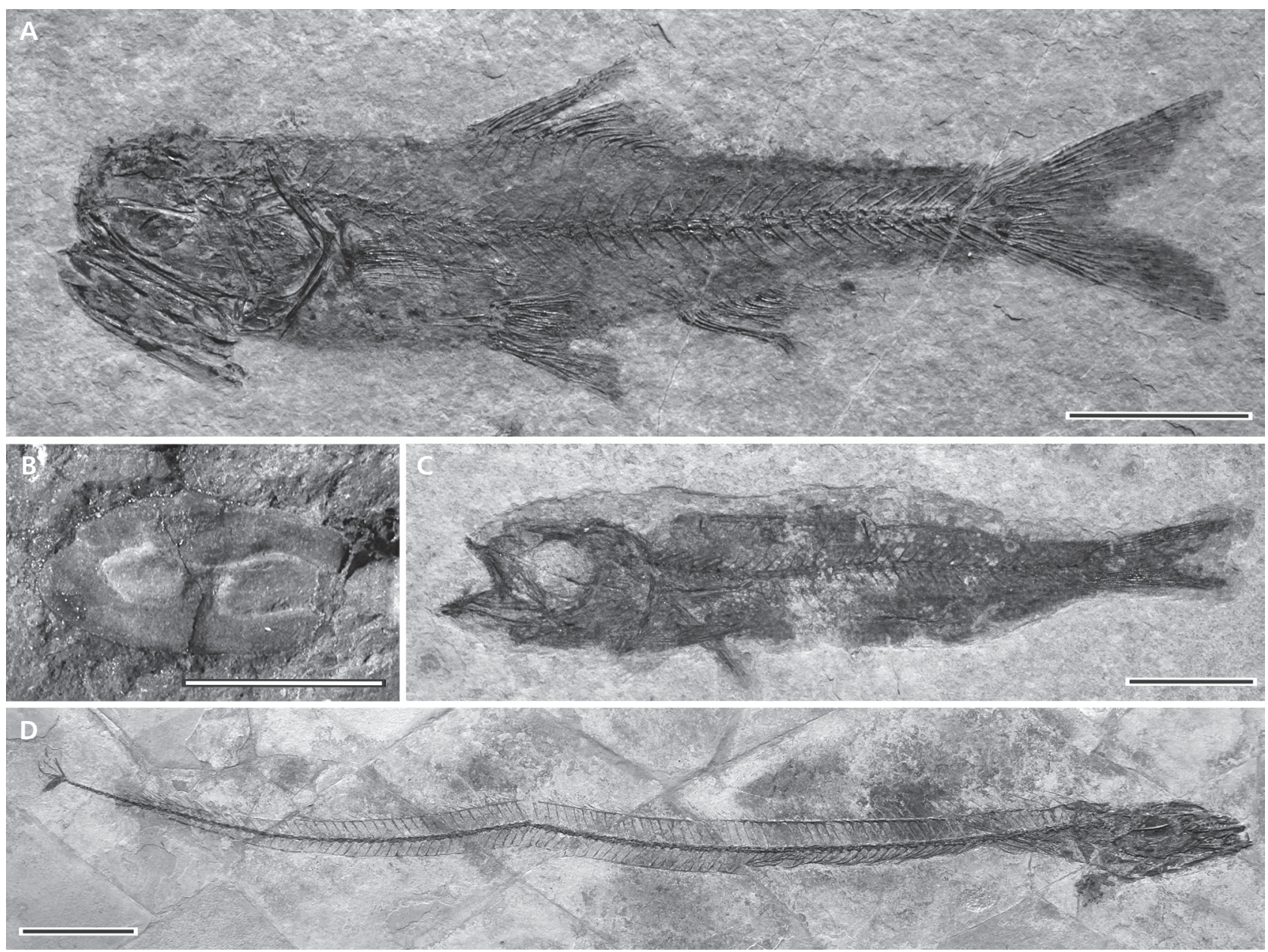

Figure 4. Teleosts from the Dynów Marl Member, Outer Carpathians, Poland: Myctophiformes, Gadiformes, and Scombriformes. • A - Oligophus moravicus, MWGUW ZI/57/093/a. • B - otolith of Palaeogadus sp., MWGUW ZI/57/138. • C - Palimphyes sp., MWGUW ZI/57/157/a. • D Anenchelum glarisianum, MSMD Ma-2/L. Scale bars equal $5 \mathrm{~mm}$ (B), $10 \mathrm{~mm}$ (A, C) and $100 \mathrm{~mm}$ (D).

10 rays, which insert close to the ventral margins of the body flanks. The pelvic fins are reduced to one flattened spine. The caudal fin is small and forked. Scales are absent.

Remarks. - In the examined material the total number of spines and soft rays of the anal and the dorsal fin is not completely clear, because of the insufficient state of preservation. The number of the pterygiophores of the dorsal fin's soft rays slightly exceeds the number of adjacent caudal vertebrae. Two or three pterygiophores are supernumerary, and situated in the interneural spaces in the middle part of the body. Each of these additional pterygiophores is located between the neural spines of the $4^{\text {th }}$ and the $6^{\text {th }}$, the $8^{\text {th }}$ and the $12^{\text {th }}$ or the $15^{\text {th }}$ and the $18^{\text {th }}$ caudal vertebrae. The investigated specimens have the main diagnostic character of Anenchelum (see Monsch \& Bannikov 2012): pelvic fin reduced to only a single spine. They have typical characters of Anenchelum, in- cluding number of vertebrae, presence of a caudal fin, presence of supernumerary pterygiophores in the dorsal fin. The combination of characters listed herein supports the attribution of the specimens to A. glarisianum (see Monsch \& Bannikov 2012), including: the total number of vertebrae, the number of abdominal and caudal vertebrae, and the lower jaw articulation facet's location beneath the middle of the orbit. The morphology of the examined specimens is fully consistent with thate of A. glarisianum reported by Gregorová $(2010,2011)$. Descriptions of specimens of $A$. glarisianum from the Menilite Formation have been given by Jerzmańska (1968), Gregorová (2010, 2011), Monsch \& Bannikov (2012), and Přikryl (2013).

Ecology of related extant forms: Trichiurids live above the bottom of the continental shelf and slope worldwide (Parin \& Nakamura 2002). Their habitats range from estuaries to open water up to $2000 \mathrm{~m}$ in depth (Gago 1998). 


\section{Discussion and conclusions}

The fish assemblage from the Dynów Marl Member of the Menilite Formation in Poland described herein comprises three shark taxa and eight teleost taxa (Figs 2-4, electronic appendix 2). 'Glossanodon' musceli, Vinciguerria obscura, and Anenchelum glarisianum (electronic appendix 2) are for the first time reported in the Dynów Marl Member in Poland. Centrophoridae indet. is for the first time reported from the Menilite Formation. Most of the taxa have previously been reported from the Oligocene deposits of the Paratethys, but the assemblage of the Dynów Marl Member of Poland has not been analyzed in order to reconstruct the paleobiogeography and paleoenvironment. Consequently, this assemblage has the potential to provide such data in the northern Central Paratethys.

\section{Paleobiogeography}

Numerous authors have postulated an intermittent marine connection in the NP23 (about 30-32 Ma) between the North Sea, the Upper Rhine Graben, the Central Paratethys (Carpathian Basin), and the Eastern Paratethys (Rögl 1999, Popov et al. 2002, Maxwell et al. 2016). A closure of marine seaways between the Paratethys and the World Ocean during the deposition of the Dynów Marl Member has been hypothesized by Studencka et al. (2016) and Sachsenhofer et al. (2017). Based on fossil fishes, the existence of a marine connection between the Upper Rhine Graben, the Central and Eastern Paratethys during the early Oligocene (28.5-34 Ma) and the Upper Rhine Graben has been interpreted as the Western Paratethys (Micklich \& Parin 1996, Micklich 1998, Pharisat \& Micklich 1998, Bannikov 2010).

Fish fauna from the Dynów Marl Member of Poland and the Dynów Marlstone of the Czech Republic is treated here as the Dynów Marls (DM) assemblage. It comprises 22 taxa of fishes, including three elasmobranch species and 19 teleost genera or species (Tab. 1). This assemblage is more similar to another assemblage of the Central Paratethys than to those of the Upper Rhine Graben and the Eastern Paratethys. The most similar fauna have been reported from Poland, the Czech Republic and Romania, containing more than $75 \%$ taxa of DM assemblage $(77 \%, 82 \%$, and $77 \%$, respectively, Tab. 1). Other fauna with high levels of similarity to the DM fauna has been described from the North Caucasus of Russia (50\%) in the Eastern Paratethys. The correlation between the DM fish assemblage and that of the Upper Rhine Graben is relatively low (41-45\%), with nine shared taxa in France and ten in Germany. The connection between the Upper Rhine Graben and the Central Paratethys in NP23 is weakly supported by the occurrence of three fishes: the teleosts Anenchelum glarisianum and Auxides cernegurae, and the shark Keasius parvus. The presence of Alopias aff. superciliosus does not support such a connection, as this species seems to show a cosmopolitan distribution. The same genera can be found in both regions, such as Palaeogadus, Palaeorhynchus, and Palimphyes, but they exhibit a broad distribution in the Eocene-Oligocene. 'Clupea' and 'Serranus' should be revised to recognize their significance in paleobiogeographic considerations.

Anenchelum glarisianum has been reported from NP23 from the Dynów Marl Member of the Menilite Formation of Poland, the Marnes à Melettes of France (Pharisat 1991), the Dynów Marlstone of the Czech Republic (Gregorová 2011), and the Bituminous Marls of Romania (Ciobanu 1977, Baciu et al. 2016). This species has also been identified in the Pshekha Horizon of Abkhazia (Monsch \& Bannikov 2012). This horizon has been correlated with NP21-22 by Sachsenhofer et al. (2017). The species has been recognized in the Rupelian of the Glarner Schiefer of Switzerland and the Menilite Formation of Ukraine (Monsch \& Bannikov 2012). The stratigraphic occurrence of the species is restricted to the Rupelian (electronic appendix 3).

Anenchelum glarisianum has furthermore been reported from Grube Unterfeld (Frauenweiler) locality in Germany (Micklich \& Hildebrandt 2010, Monsch \& Micklich 2018). The sediments of this locality belong to the Hochberg Member or the Bodenheim Formation (Maxwell et al. 2016). Referring to the materials of the Grube Unterfeld ("Frauenweiler") locality in BadenWürttemberg (S. Germany), Monsch \& Micklich (2018) have considered all specimens that have previously been assigned to A. glarisianum either as representatives of two undescribed new species of Anenchelum or as Anenchelum sp.

Keasius parvus is known from NP23 from the Marnes à Melettes of France (Pharisat 1991), the Hochberg Member of the Bodenheim Formation of Germany (Maxwell et al. 2016), the Dynów Marl Member of Poland, the Dynów Marlstone of the Czech Republic (Cappetta et al. 2016), and the Bituminous Marls of Romania (Baciu et al. 2016). The species has furthermore been reported from the Rupelian of the Glarner Schiefer of Switzerland (Welton 2013), the Azley Formation of Mainz Basin in Germany, and the Boom Clay Formation of the southern part of the North Sea Basin in Belgium (Reinecke et al. 2001, Cappetta et al. 2016).

Auxides cernegurae has been reported from the Hochberg Member of Bodenheim Formation (Maxwell et al. 2016) and Grube Unterfeld locality (Monsch \& Micklich 2018), with sediments of the same formation of Germany, the Bituminous Marls of Romania and the lower part of the Menilite Formation of Ukraine (Monsch \& Bannikov 

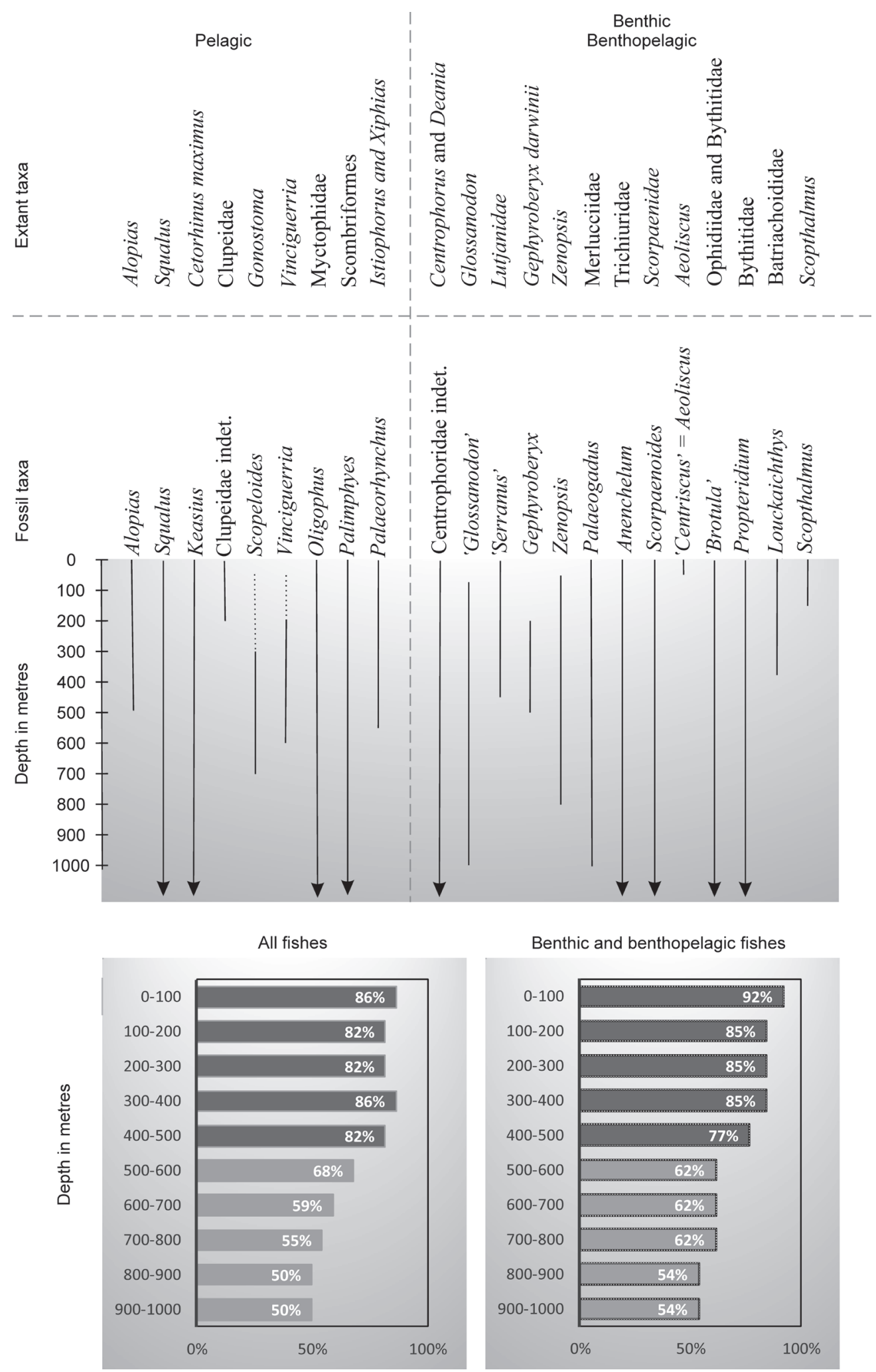

Figure 5. Paleobathymetric analysis: bathymetric ranges of elasmobranch and teleostean taxa in the Dynów Marl Member (Outer Carpathians, Poland) and the Dynów Marlstone (Outer Carpathians, Czech Republic), and results of all the taxa and the benthic-benthopelagic taxa. Taxa names in black - taxa described in this study, taxa names in grey - taxa reported in previous publications by Cappetta et al. (2016), Gregorová (2011), Kotlarczyk et al. (2006), and Přikryl \& Carnevale $(2017,2018)$. Dotted lines indicate the distribution of mesopelagic taxa at night, those distributions are not considered. 
Table 1. Distribution of the genera and species identified in the Dynów Marls: the Dynów Marl Member (Outer Carpathians, Poland) and the Dynów Marlstone (Outer Carpathians, the Czech Republic) in other regions in the lower Oligocene. Abbreviations: $x$ - presence in NP23; R - presence in the Rupelian; xR - presence in NP23 and other periods of the Rupelian (Jonet 1958; Jerzmańska 1968; Ciobanu 1977; Pharisat 1991; Pharisat \& Micklich 1998; Constantin 1999; Brzobohatý \& Nolf 1995; Reinecke et al. 2001; Prokofiev 2005b, 2006; Kotlarczyk et al. 2006; Bannikov 2010; Micklich \& Hildebrandt 2010; Gregorová 2011; Monsch \& Bannikov 2012; Přikryl et al. 2012, 2017; Welton 2013; Baciu et al. 2016; Cappetta et al. 2016; Maxwell et al. 2016; Gradianu et al. 2017; Přikryl \& Carnevale 2017, 2018; Bordeianu et al. 2018; Brzobohatý \& Bubík 2019).

\begin{tabular}{|c|c|c|c|c|c|c|c|c|c|c|c|c|c|}
\hline $\begin{array}{l}\text { taxa, Dynów } \\
\text { Marls: Dynów }\end{array}$ & $\begin{array}{l}\text { Switzer- } \\
\text { land }\end{array}$ & France & Germany & Germany & Belgium & Poland & $\begin{array}{c}\text { this } \\
\text { study } \\
\text { Poland }\end{array}$ & $\begin{array}{c}\text { Czech } \\
\text { Republic }\end{array}$ & Ukraine & Romania & $\begin{array}{l}\text { Russia } \\
\text { North } \\
\text { Caucasus }\end{array}$ & $\begin{array}{l}\text { Abkha- } \\
\text { zia }\end{array}$ & $\begin{array}{l}\text { Azer- } \\
\text { baijan }\end{array}$ \\
\hline $\begin{array}{l}\text { and Dynów } \\
\text { Marlstone }\end{array}$ & $\begin{array}{c}\text { north- } \\
\text { western } \\
\text { Tethys }\end{array}$ & $\begin{array}{l}\text { Upper } \\
\text { Gro }\end{array}$ & $\begin{array}{l}\text { r Rhine } \\
\text { aben }\end{array}$ & North & h Sea & & & ntral Parate & thys & & \multicolumn{3}{|c|}{ Eastern Paratethys } \\
\hline Keasius parvus & $\mathrm{R}$ & $\mathrm{x}$ & $\mathrm{x}$ & $\mathrm{R}$ & $\mathrm{R}$ & $\mathrm{x}$ & $\mathrm{x}$ & $\mathrm{x}$ & & $\mathrm{x}$ & & & \\
\hline $\begin{array}{l}\text { Squalus cf. } \\
\text { alsaticus }\end{array}$ & & & $\mathrm{x}$ & $\mathrm{R}$ & & & & $\mathrm{x}$ & & & & & \\
\hline $\begin{array}{l}\text { Alopias aff. } \\
\text { superciliosus }\end{array}$ & & & $\mathrm{R}$ & & $\mathrm{R}$ & $\mathrm{x}$ & $\mathrm{x}$ & $\mathrm{x}$ & & & & & \\
\hline 'Clupea' & & $\mathrm{x}$ & $\mathrm{x}$ & & & $\mathrm{R}$ & & $\mathrm{x}$ & $\mathrm{x}$ & $\mathrm{x}$ & $\mathrm{x}$ & $\mathrm{x}$ & $\mathrm{x}$ \\
\hline $\begin{array}{l}\text { 'Clupea } \\
\text { sardinites' }\end{array}$ & & $\mathrm{x}$ & $\mathrm{x}$ & $\mathrm{x}$ & & $\mathrm{R}$ & & $\mathrm{xR}$ & & $\mathrm{xR}$ & & & \\
\hline $\begin{array}{l}\text { 'Glossanodon' } \\
\text { musceli }\end{array}$ & & & & & & $\mathrm{x}$ & $\mathrm{x}$ & $\mathrm{x}$ & & $\mathrm{x}$ & & & \\
\hline $\begin{array}{l}\text { Scopeloides } \\
\text { glarisianus }\end{array}$ & $\mathrm{R}$ & & & & & $\mathrm{xR}$ & $\mathrm{x}$ & $\mathrm{xR}$ & $\mathrm{R}$ & $x R$ & $\mathrm{R}$ & $\mathrm{R}$ & $\mathrm{R}$ \\
\hline $\begin{array}{l}\text { Vinciguerria } \\
\text { obscura }\end{array}$ & & & & & & $\mathrm{xR}$ & $\mathrm{x}$ & $\mathrm{x}$ & $\mathrm{R}$ & $\mathrm{xR}$ & $\mathrm{R}$ & $\mathrm{R}$ & $\mathrm{R}$ \\
\hline $\begin{array}{l}\text { Oligophus } \\
\text { moravicus }\end{array}$ & & & $\mathrm{R}$ & & & $\mathrm{xR}$ & $\mathrm{x}$ & $\mathrm{x}$ & $\mathrm{R}$ & $\mathrm{x}$ & $\mathrm{R}$ & $\mathrm{R}$ & $\mathrm{R}$ \\
\hline 'Serranus' & & $\mathrm{x}$ & $\mathrm{x}$ & & & $\mathrm{xR}$ & & & & $\mathrm{R}$ & $\mathrm{R}$ & & \\
\hline $\begin{array}{l}\text { Gephyroberyx } \\
\text { cf. darwinii }\end{array}$ & & & & & & & & $\mathrm{x}$ & & $\mathrm{R}$ & $\mathrm{R}$ & & \\
\hline Zenopsis clarus & & & & & & $\mathrm{R}$ & & $\mathrm{x}$ & & $\mathrm{R}$ & $\mathrm{R}$ & & \\
\hline Palaeogadus & $\mathrm{R}$ & $\mathrm{x}$ & $\mathrm{x}$ & $\mathrm{R}$ & & $\mathrm{xR}$ & $\mathrm{x}$ & $\mathrm{xR}$ & & $x R$ & $\mathrm{R}$ & & \\
\hline Palimphyes & $\mathrm{R}$ & $\mathrm{x}$ & & & & $x R$ & $\mathrm{x}$ & $\mathrm{x}$ & & $\mathrm{R}$ & $\mathrm{R}$ & $\mathrm{R}$ & \\
\hline $\begin{array}{l}\text { Anenchelum } \\
\text { glarisianum }\end{array}$ & $\mathrm{R}$ & $\mathrm{x}$ & & & & $\mathrm{xR}$ & $\mathrm{x}$ & $\mathrm{xR}$ & $\mathrm{R}$ & $\mathrm{xR}$ & & $\mathrm{R}$ & \\
\hline Palaeorhynchus & & $\mathrm{x}$ & $\mathrm{x}$ & & & $x R$ & & & $\mathrm{R}$ & $\mathrm{R}$ & $\mathrm{R}$ & & \\
\hline Scorpaenoides & & & & & & $x R$ & & & & $\mathrm{xR}$ & & & \\
\hline $\begin{array}{l}\text { 'Centriscus' = } \\
\text { Aeoliscus }\end{array}$ & & $\mathrm{x}$ & $\mathrm{x}$ & & & $x R$ & & & & $\mathrm{x}$ & $\mathrm{x}$ & & \\
\hline $\begin{array}{l}\text { 'Brotula' } \\
\text { longipinnata }\end{array}$ & & & & & & & & $\mathrm{x}$ & & & & & \\
\hline $\begin{array}{l}\text { Propteridium } \\
\text { profondae }\end{array}$ & & & & & & & & $\mathrm{x}$ & & & & & \\
\hline $\begin{array}{l}\text { Louckaichthys } \\
\text { novosadi }\end{array}$ & & & & & & & & $\mathrm{x}$ & & & & & \\
\hline $\begin{array}{l}\text { Scopthalmus } \\
\text { stamatini }\end{array}$ & & & & & & & & $\mathrm{x}$ & & $x R$ & & & \\
\hline In common with & & & & & & & & & & & & & \\
\hline $\begin{array}{l}\text { Dynów Marls } \\
\text { (number of taxa) }\end{array}$ & 5 & 9 & 10 & 4 & 2 & 17 & 9 & 18 & 6 & 17 & 11 & 6 & 4 \\
\hline $\begin{array}{l}\text { In common with } \\
\text { Dynów Marls }\end{array}$ & $23 \%$ & $41 \%$ & $45 \%$ & $18 \%$ & $9 \%$ & $77 \%$ & $41 \%$ & $82 \%$ & $27 \%$ & $77 \%$ & $50 \%$ & $27 \%$ & $18 \%$ \\
\hline
\end{tabular}


2012). This species is also known from the Pshekha Horizon of Abkhazia and the North Caucasus in Russia (Monsch \& Bannikov 2012).

Scopeloides glarisianus, Vinciguerria obscura, and Oligophus moravicus have been reported from the lower Oligocene zones NP21-23 of the Central and Eastern Paratethys. They have also been described from the Dynów Marl Member of Poland, the Dynów Marlstone of the Czech Republic (Gregorová 1988, 2011), the Kotów Chert Member of Poland (Kotlarczyk et al. 2006), the lower part of Menilite Formation of Ukraine (Prokofiev 2005b, 2006), the Bituminous Marls of Romania (Ciobanu 1977, Baciu et al. 2016, Grădianu et al. 2017), and the Aeoliscus beds of the Pshekha Horizon of the North Caucasus in Russia and Abkhazia, which are analogs of the Pshekha Horizon of Azerbaijan (Prokofiev 2005b, 2006). The Rupelian Glarner Schiefer of Switzerland and the Middle to Late Eocene Pabdeh Formation of Iran contain Scopeloides glarisianus (Grădianu et al. 2017), too.

The shark Alopias aff. superciliosus is known from NP23 from the Dynów Marlstone of Czech Republic (Cappetta et al. 2016). The species hass been reported from the Rupelian of the Azley Formation of the Mainz Basin in Germany and the Boom Clay Formation of the southern part of the North Sea Basin in Belgium (Reinecke et al. 2001, Cappetta et al. 2016).

The distribution of Anenchelum glarisianum, Auxides cernegurae, Keasius parvus, Scopeloides glarisianus, Vinciguerria obscura, and Oligophus moravicus (Tab. 1) confirms a marine connection during the Rupelian between the Upper Rhine Graben, the northwestern Tethys, and the Central (Carpathian Basin) and Eastern Paratethys. The occurrence of the shark K. parvus supports a marine connection during the Rupelian between the North Sea, the Upper Rhine Graben and the Central Paratethys (Carpathian Basin). The close relative of this species, the recent Cetorhinus, is cosmopolitan. Therefore, further research is necessary to assess the significance of this species.

\section{Paleoenvironment}

The composition of the ichthyofauna is herein used to evaluate the paleobathymetric range, via a comparison with the depth range of related extant taxa, according to the methods described and discussed by Nolf \& Brzbohaty (1994) and Lin et al. (2016). The paleobathymetric method is based on the analysis of taxa reported here and previously in the Dynów Marl Member in Poland and in the Dynów Marlstone in the Czech Republic. Corresponding information concerning the applicable extant taxa has already been given in the preceding text (Systematic Paleontology - Ecology of related extant forms), and for taxa reported previously and not described here, information has been taken from Cappetta et al. (2016), Froese \& Pauly (2021), Greenfield et al. (2008), Kotlarczyk et al. (2006), and Møller et al. (2016). For the results, the analysis and the associated diagrams, see Fig. 5. For some of the Dynow Marls taxa it is, however, not possible to state which species are related to the fossil taxa, and so the depth distribution of all extant species of the same genus or family has been taken into account.

The ichthyofaunal assemblage of the Dynów Marl Member and the Dynów Marlstone contains the highest percentage $(78-87 \%)$ of fishes in the depth interval between 0 and $500 \mathrm{~m}$ (Fig. 5). The assemblage of benthic and benthopelagic fishes contains the highest percentage (71-93\%) in the same interval. The benthic and benthopelagic taxa are more important for the bathymetric interpretation (Lin et al. 2016).

Consequently, it can be concluded that the fish assemblage of the Dynów Marls predominantly lived in the depth interval between the sea level and a depth of about $500 \mathrm{~m}$, confirming the variable depths of the basin, including a deep-water as well as a shallow sea environment that prevailed during the deposition of the Dynów Marl Member and the Dynów Marlstone of the Menilitic Formation in the northern Central Paratethys.

This conclusion is consistent with the analysis by Cappetta et al. (2016) of the shark assemblage of the Menilitic Formation in the Czech Republic. This assemblage contains $78-89 \%$ of fishes in the depth interval between 0 and $500 \mathrm{~m}$. The ichthyofauna of the Upper Rhine Graben contains more than $80 \%$ of fishes in the depth interval between 0 and $50 \mathrm{~m}$, about $50-60 \%$ in the depth interval between 50 and $200 \mathrm{~m}$, and less than $20 \%$ in the depth interval between 400 and $800 \mathrm{~m}$, indicating distinctly shallower waters (Maxwell et al. 2016). The absence of deep-water taxa like Scopeloides glarisianus, Vinciguerria obscura, and Oligophus moravicus in the Upper Rhine Graben (Western Paratethys) corresponds well to a moderately shallow environment. The absence of these fishes in the Polbian Bed in the Eastern Paratehys (Russian localities, North Caucasus) may result from the absence of sufficiently deep zones in the basin.

The bathymetric distribution of fishes of the Dynów Marls supports the presence of oxygenated epi- and mesopelagic zones, as well as sublittoral and upper bathyal zones in the northern Central Paratethys. However, an unbioturbated, mostly dark-brown sediment that contains well-preserved skeletons of fishes is indicative of anoxic waters at and above the sea floor (Fig. 6). This is supported by the limited presence of typical demersal fishes and the paucity of benthic fauna. Therefore, considering the presence of anoxic waters, the basin was likely deeper than $500 \mathrm{~m}$. 


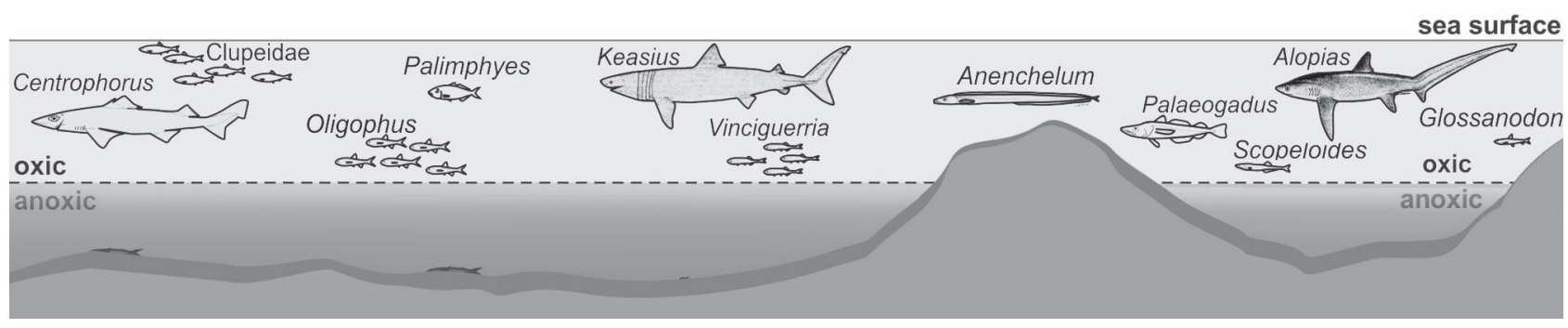

Figure 6. Reconstruction of the paleoenvironment in the Central Paratethys during the deposition of the Dynów Marl Member of the Menilite Formation (early Oligocene, about $32 \mathrm{Ma}$ ).

The low-diversity-specific bivalve assemblages, a specific ostracod association, and a nearly monotypic calcareous nannoplankton flora from the Paratethys during the middle Rupelian suggest reduced salinity, estimated between 12 and 15\%o (Rusu 1988, Popov et al. 2002, Melinte-Dobrinescu \& Bruster 2008, Studencka et al. 2016). During the deposition of the Dynów Marl Member brackish conditions have been hypothesized (Studencka et al. 2016).

According to the life habits of individuals of extant comparative species, the Dynów Marl Member bears a typical marine ichthyofauna. Typical brackish fishes have not been recovered, and euryhaline fishes may only be represented by some species of Bythitidae, Clupeidae, Merlucciidae, Ophidiidae, Trichiuridae, and Scopthalmus. Kotlarczyk et al. (2006) have reported freshwater Barbus, based on the presence of a single scale. Most previous records of freshwater fishes in the Oligocene of the Carpathians after revision have not been confirmed (e.g., Jerzmańska 1968, Constantin 1999). This record is not listed in paleobathymetric analyses and palebioogeographic considerations, because in needs to be reviewed or supported by the presence of additional specimens. Extant representatives of the families Gonostomatidae, Phosichthyidae, and Myctophidae, are typical of a fully marine environment, where they inhabit the deep pelagic zones (shared depth range between

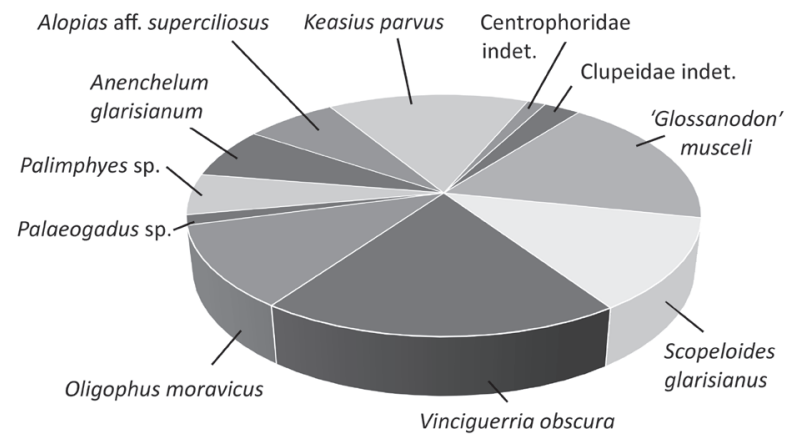

Figure 7. Relative percentage values of the various fish taxa with respect to the complete fish assemblage of the the Dynów Marl Member described here, the total number of specimens is 73 .
300 and $600 \mathrm{~m}$ ). Records that can be assigned to these families constitute a significant part of the fish assemblage described in this paper (42\%, Fig. 7). Therefore, normal salinity can be inferred for the upper part of the mesopelagic zone during the deposition of the Dynów Marl Member.

Brackish conditions can be hypothesized locally (based on bivalve, ostracod and nannoplankton assemblages), near the freshwater influx or in surface waters and shallow-marine benthic waters.

\section{Stratigraphic significance}

The ichthyofaunal zone IPM1 of the Carpathian Oligocene was correlated with the assemblage of the Pshekha Horizon in the Eastern Paratethys by Jerzmańska \& Kotlarczyk (1983). Based on the occurrence of Aeoliscus, Vinciguerria obscura, Oligophus moravicus, and Scopeloides glarisianus, the Carpathian ichthyofaunal zone IPM1 has been regarded by Prokofiev (2007) as contemporaneous with the upper Pshekian stage of the Eastern Paratethys. In the Carpathians (Central Paratethys), the IPM1 zone has been correlated with the Kotów Chert Member and the Dynów Marl Member (Kotlarczyk et al. 2006). Therefore, the present ichthyofauna supports a correlation between the upper Pshekian stage of the Eastern Paratethys and the Dynów Marl Member of the Central Paratethys. By contrast, many authors correlate the early Solenovian (Polbian) stage of the Eastern Paratethys with the Dynów Marl Member (Studencka et al. 2016; Sachsenhofer et al. 2017, 2018). Prokofiev (2007) has correlated the early Solenovian with IPM 2. This correlation is affected by a distinctly reduced number of fishes in the early Solenovian in comparison to the upper Pshekian. This scarcity of fishes may result from significant changes in the environment of the Eastern Paratethys, specifically dectreased salinity and the shallowing of the sea. Therefore, it is concluded here that particular ichthyofauna of the Dynów Marl Member links this unit with the upper Pshekian stage of the Eastern Paratethys. The deviations between the assemblages of the Dynów Marl Member and the early Solenovian probably 
owe to considerable paleoenvironmental differences between the Central and the Eastern Paratethys.

Based on the occurrence of Vinciguerria obscura, Oligophus moravicus, and Scopeloides glarisianus, a correlation among the Dynów Marl Member of Poland, the Dynów Marlstone of the Czech Republic, the lower part of the Menilite Formation of Ukraine, and the Bituminous Marls of Romania is confirmed.

\section{Acknowledgments}

I thank W. Schwarzhans for consultation of determination of the otolith specimen; R. Szybiak (MSMD) for access to the specimens; A. Jamróz, M. Pałdyna, M. Granica, R. Czerwiński for the donation of specimens. I am grateful to Dr. Norbert Micklich and anonymous journal reviewer for constructive comments on the manuscript. Funding for the project was supplied by University of Warsaw IGP BSt 173502 (2015).

\section{References}

Agassiz, L. 1833-1844. Recherches sur les poissons fossiles. 1420 pp. 5 vols. Petitpierre. Neuchatel.

DOI 10.5962/bhl.title.4275

Baciu, D.S., Grădianu, I., Seserman, A. \& Dumitriu, T.C. 2016. Oligocene fish fauna and sedimentological particularities of the Bituminous Marls of the Vrancea Nappe, Eastern Carpathians, Romania. Analele Stiintifice ale Universitatii "Al. I. Cuza” din Iasi, Seria Geologie 62, 29-46.

BÁLDI, T. 1989. Tethys and Paratethys through Oligocene times. Remarks and comment. Geologica Carpathica 40, 85-99.

Bannikov, A.F. 2010. Fossil Vertebrates of Russia and Adjacent Countries: Fossil Spiny Rayed Fishes (Teleostei, Acanthopterygii). 243 pp. GEOS, Moscow. [in Russian]

Berg, L.S. 1958. System der Rezenten und Fossilen Fischartigen und Fische. 310 pp. Deutsche Verlag Wissenschaften, Berlin, Germany.

Bertelsen, E. 1958. The argentinoid fish Xenophthalmichthys danae. Dana-Report 45, 1-8.

Bieńkowska-Wasiluk, M. 2010. Taphonomy of Oligocene teleost fishes from the Outer Carpathians of Poland. Acta Geologica Polonica 60(4), 479-533.

Bieńkowska-Wasiluk, M. \& Radwanski, A. 2009. A new occurrence of sharks in the Menilite Formation (Lower Oligocene) from the Outer (Flysch) Carpathians of Poland. Acta Geologica Polonica 59(2), 235-243.

Blainville, H.D. DE 1818. Sur les ichthyolites ou les poissons fossils, 310-395. In Nouveau Dictionnaire d'Histoire Naturelle, appliquée aux Arts, à l'Economie Rurale et Domestique, à la Médicine, etc. 27. Deterville, Paris.

BleEker, P. 1859. Enumeratio specierum piscium hucusque in Archipelago indico observatarum adjectis habitationibus citationibusque, ubi descriptions earum recentiores reperiuntur, nec non speciebus Musei Bleekeriani Bengalensibus,
Japonicus, Capensibus Tasmanicisque. Acta Societatis Regiae Scientiarum Indo-Neerlandicae 6, 1-276.

Bonaparte, C.L. 1838. Selachorum tabula analytica. Nuovi Annali delle Scienze Naturali, Bologna 2, 195-214.

Bonaparte, C.L. 1846. Catalogo metodico dei pesci europei. Atti della Settima Adunanza degli Scienziati Italiani, Sesta Riunione, Milano 7 a Adunanza 2, 1-95.

DOI 10.5962/bhl.title.59507

Bordeianu, M., Grădianu, I., Trif, N. \& Codrea, V. 2018. Commented list of the lower Oligocene fish fauna from the Coza Valley (Marginal Folds Nappe, Eastern Carpathians, Romania). Oltenia. Studii și comunicări. Științele Naturii 34, 7-14.

Bräger, Z. \& Moritz, T. 2016. A scale atlas for common Mediterranean teleost fishes. Vertebrate Zoology 66, 275-386.

Bratishio, A. \& Udovichenko, M. 2013. Fish otoliths from the Early Oligocene of Mangyshlak, Kazakhstan. Neues Jahrbuch für Geologie und Paläontologie, Abhandlungen 270, 195-208. DOI 10.1127/0077-7749/2013/0366

Brzoвohatý, R. \& Bubík, M. 2019. Paleogene fish otoliths (Teleostei) from the Subsilesian and Ždánice units in Moravia. Bulletin of Geosciences 94, 101-114.

DOI 10.3140/bull.geosci.1715

Brzobohatý, R. \& Nolf, D. 1995. Diaphus otoliths from the European Oligocene (Myctophidae, Teleostei). Bulletin de l'Institut royal des Sciences naturelles de Belgique, Sciences de la Terre 65, 257-268.

Cappetta, H., Gregorová, R. \& Adnet, S. 2016. New selachian assemblages from the Oligocene of Moravia (Czech Republic). Neues Jahrbuch für Geologie und Paläontologie, Abhandlungen 280, 259-284.

DOI 10.1127/njgpa/2016/0579

Carpenter, K.E., Collette, B.B. \& Russo, J.L. 1995. Unstable and stable classifications of scombroid fishes. Bulletin of Marine Science 56, 379-405.

Ciobanu, M. 1977. Fauna fossilă din Oligocenul de la Piatra Neamt. 159 pp. Editura Academiei Republici Socialiste Romănia, Romania, Bucuresti.

Cohen, D.M., Inada, T., Imamoto, T. \& Scialabba, N. 1990. FAO species catalogue. Vol. 10. Gadiform fishes of the world (order Gadiformes). An annotated and illustrated catalogue of cods, hakes, grenadiers and other gadiform fishes known to date. FAO Fisheries Synopsis 125(10), 1-442.

Collette, B.B., Reeb, C. \& Block, B.A. 2001. Systematics of the tunas and mackerels (Scombridae). Fish Physiology 19, 1-33. DOI 10.1016/S1546-5098(01)19002-3

Compagno, L.J.V. 1984. Sharks of the World: An annotated and illustrated catalogue of shark species known to date. Part 1: Hexanchiformes to Lamniformes. 249 pp. FAO Species Catalogue, 4. Roma: Food and Agriculture Organization of the United Nations.

Compagno, L.J.V. 2002. Sharks of the World. An annotated and illustrated catalogue of shark species known to date. Vol 2. Bullhead, mackerel and carpet sharks (Heterodontiformes, Lamniformes and Orectolobiformes). 269 pp. FAO Species Catalogue for Fishery Purposes. FAO of the United Nations, Rome.

Compagno, L.J.V., Dando, M. \& Fowler, S. 2005. A Field Guide 
to the Sharks of the World. 368 pp. Harper Collins, London.

Constantin, P. 1999. Oligocene-Lowermost Miocene fossil fishfauna (Teleostei) from Romanian Eastern Carpathians. Geo-eco-marina 4, 119-134.

Cuvier, G. 1817. Le Règne Animal distribué d'après son organisation pour servir de base à l'histoire naturelle des animaux et d'introduction à l'anatomie comparée. Les reptiles, les poissons, les mollusques et les annélides. Vol. 2.532 pp. A. Belin, Paris.

Daniltshenko, P.G. 1946. Luminous fishes of the family Gonostomidae from the Tertiary deposits of the Caucasus and the Crimea. Izvestia Akademii Nauk Soyuza SSR. Otdelenie Biologicheskich Nauk 6, 639-646. [in Russian]

Daniltshenko, P.G. 1960. Bony fishes of the Maikop Deposits of the Caucasus. Trudy Paleontologicheskogo Instituta Akademii Nauk SSSR 78, 1-208. [in Russian]

DzIADZIo, P.S. 2018. Sedimentary environment of the Menilite Beds in the Stróże Thrust Sheet, Silesian Unit, Carpathians. Nafta-Gaz 11, 813-820. DOI 10.18668/NG.2018.11.05

Dziadzio, P.S., Matyasik, I., Garecka, M. \& Szydlo, A. 2016. Lower Oligocene Menilite Beds, Polish Outer Carpathians: supposed deep-sea flysch locally reinterpreted as shelfal, based on new sedimentological, micropalaeontological and organic-geochemical data. Prace Naukowe Instytutu Nafty i Gazu - Państwowy Instytut Badawczy 213, 1-120.

DOI 10.18668/PN2016.213

Endo, H. 2002. Phylogeny of the order Gadiformes (Teleostei, Paracanthopterygii). Memoirs of the Graduate School of Fisheries Sciences Hokkaido University 49, 75-149.

Fedotov, V.F. 1980. Order Gadiformes, 62-82. In NovitskayA, L.I. (ed.) Fossil Bony Fishes of the SSSR. Trudy Paleontologicheskogo Instituta Akademii Nauk SSSR 178. [in Russian]

Froese, R. \& Pauly, D. (eds) 2021. FishBase. World Wide Web electronic publication. Available at www.fishbase.org Accessed February 25, 2021.

GaGo, F.J. 1998. Osteology and phylogeny of the cutlassfishes (Scombroidei: Trichiuridae). Contribution in Science 476, 1-79.

GILL, T.N. 1862. Analytical synopsis of the Order of Squali and revision of the nomenclature of the genera: Annals of the Lyceum of Natural History of New York 7, 367-408. DOI 10.1111/j.1749-6632.1862.tb00166.x

GiLl, T.N. 1884. On the anacanthine fishes. Proceedings of the Academy of Natural Sciences of Philadelphia 36, 167-183.

GiLl, T.N. 1893. Families and subfamilies of fishes. Memoirs of the National Academy of Sciences Washington 6, 127-138. DOI 10.5962/bhl.part.6303

Goodrich, E.S. 1909. Sub-Grade 3. Osteichthyes, 210-229. In Lankester, E.R. (ed.) A Treatise on Zoology, Part IX, The Vertebrata Craniata (First Fascicle: Cyclostomes and Fishes). Adam and Charles Black, London.

DOI 10.5962/bhl.title. 13773

GóRniaK, K. 2011. Origin of the marls from the Polish Outer Carpathian: lithological and sedimentological aspects. Mineralogia 42, 165-297. DOI 10.2478/v10002-011-0012-9

Grădianu, I., Přikryl, T., Gregorová, R. \& Harold, A.S. 2017. $\dagger$ Gonostoma dracula sp. nov. (Teleostei, Gonostomatidae) from the Oligocene deposits of the Central Paratethys
(Romania): earliest occurrence of the modern bristlemouths. Bulletin of Geosciences 92, 323-336.

DOI 10.3140/bull.geosci.1683

Grădianu, I., Přikryl, T. \& Gregorová, R. 2020. Revision of the genera Vinciguerria and $\dagger$ Eovinciguerria from the Oligocene of Romania (Central Paratethys) - comments on selected characters. Neues Jahrbuch für Geologie und Paläontologie, Abhandlungen 298, 251-267. DOI 10.1127/njgpa/2020/0947

Greenfield, D.W., Winterbottom, R. \& Collette, B.B. 2008. Review of the toadfish genera (Teleostei: Batrachoididae). Proceedings of the California Academy of Sciences 59, 665-710.

GregorovÁ, R. 1988. The ichthyofauna of the Menilitic Formation in the locality Litenčice and its stratigraphic position. Acta Musei Moraviae, Scientiae naturalis 73, 83-88.

GregorovÁ, R. 1997. Ostéologie de l'espece oligocene Scopeloides glarisianus (Teleostei, famille de Gonostomatidae). Acta Musei Moraviae, Scientiae geologicae 82, 123-136.

GregorovÁ, R. 2000. Analyse morphologique et ostéologique de Vinciguerria obscura Danilchenko, 1946 (Teleostei, famille de Photichthyidae) d'Oligocčne des Carpathes (Républic Tchèque). Acta Musei Moraviae, Scientiae geologicae 85, 151-161.

GregorovÁ, R. 2004. A new Oligocene genus of lanternfish (family Myctophidae) from the Carpathian Mountains. Revue de Paléobiologie, Genève, Vol. Spéc. 9, 81-97.

GregorovÁ, R. 2010. Osteological and morphological analysis of the scabbardfish Anenchelum glarisianum Blainville, 1818 (Trichiuridae) from the Menilitic Formation of the Moravian, part of West Carpathians (Oligocene, Rupelian). Acta Musei Moraviae, Scientiae geologicae 95, 141-149.

GregorovÁ, R. 2011. Fossil fish fauna (Teleostei, Selachii) from the Dynów marlstone (Rupelian, NP 23) of the Menilitic Formation at the locality of Litenčice (Czech Republic). Acta Musei Moraviae, Scientiae geologicae 96, 3-33.

Guichenot, A. 1867. Ichthyologie. III. L'Argentine léioglosse, nouveau genre de Salmonoides. Annales de la Société Linnéenne du Département de Maine-et-Loire 9, 15-17.

Harold, A.S. \& Weitzman, S.H. 1996. Interrelationships of stomiiform fishes, 333-353. In Stiassny, M.L.J., Parenti, L.R. \& Johnson, G.D. (eds) The Interrelationships of Fishes. Academic Press, San Diego, California. DOI 10.1016/B978-012670950-6/50014-X

HaY, O.P. 1902. Bibliography and Catalogue of the Fossil Vertebrata of North America. Bulletin of the United States Geological Survey 179, 1-868. DOI 10.5962/bhl.title.20094

HuXLEY, T.H. 1880. On the application of the laws of evolution to the arrangement of the Vertebrata, and more particularly of the Mammalia. Proceedings of the Zoological Society London 43, 649-662.

JANKOWSKI, L. 2015. Nowe spojrzenie na budowę geologiczną Karpat-ujęcie dyskusyjne. Prace Naukowe Instytutu Nafty i Gazu 202, 1-154.

JerzmańsKa, A. 1967. Argentinidés (Poissons) fossiles de la série ménilitique des Karpates. Acta Palaeontologica Polonica 12, 195-211.

JERZMAŃSKA, A. 1968. Ichtyofaune des couches a menilite (flysch des Karpathes). Acta Palaeontologica Polonica 13, 379-487. 
JerZMAŃSKA, A. \& KotLARCZYK, J. 1983. Ichthyofauna changes in the Tertiary of the Carpathians and of the Caucasus, 191-198. In Travaux du 12-éme congrès de l'association géologique carpatho-balkanique. Stratigraphie et Paléontologie. Annuaire de l'Institut de Géologie et de Géophysique, Bucureşti 59.

Jonet, S. 1958. Contributions à l'étude des schistes disodyliques oligocènes de Roumanie. La faune ichtyologique de Homoraciu District de Prahova. 112 pp. Lisboa.

KLEIN, E.F. 1885. Beiträge zur Bildung des Schädels der Knochenfische, 2. Jahreshefte des Vereins für Vaterländische Naturkunde in Württemberg 42, 205-300.

Kotlarczyк, J. \& Uchman, A. 2012. Integrated ichnology and ichthyology of the Oligocene Menilite Formation, Skole and Subsilesian nappes, Polish Carpathians: A proxy to oxygenation history. Palaeogeography, Palaeoclimatology, Palaeoecology 331-332, 104-118. DOI 10.1016/j.palaeo.2012.03.002

KotlarczyK, J., JerzmańSKa, A., ŚwidNicKa, E. \& WisZniowsKa, T. 2006. A framework of ichthyofaunal ecostratigraphy of the Oligocene-Early Miocene strata of the Polish Outer Carpathian basin. Annales Societatis Geologorum Poloniae 76, $1-111$.

Kováč, M., Král, J., Márton, E., Plašienka, D. \& Uher, P. 1994. Alpine uplift history of the Central Western Carpathians: geochronological, paleomagnetic, sedimentary and structural data. Geologica Carpathica 45, 83-96.

Kováč, M., Baráth, I. \& Nagymarosy, A. 1997. The Miocene collapse of the Alpine-Carpathian-Pannonian junction - an overview. Acta Geologica Hungarica 40, 241-264.

Kováč, M., Plašienka, D., Soták, J., VojtKo, R., Oszczypko, N., Less, G., Ćosović, V., Fügenschuh, B. \& Králiková, S. 2016. Paleogene palaeogeography and basin evolution of the Western Carpathians, Northern Pannonian domain and adjoining areas. Global and Planetary Change 140, 9-27. DOI 10.1016/j.gloplacha.2016.03.007

Kováč, M., HudáčKová, N., Halásová, E., Kováčová, M., Holcová, K., OszczypKo-Clowes, M., Báldi, K., Less, G., Nagymarosy, A., Ruman, A., Klučiar, T. \& Jamrich, M. 2017. The Central Paratethys palaeoceanography: a water circulation model based on microfossil proxies, climate, and changes of depositional environment. Acta Geologica Slovaca 9, 75-114.

KRHOVSKÝ, J. 1981. Microbiostratigraphic correlation in the Outer Flysch Units of the Southern Moravia and influence of the eustasy on their paleogeographic development. Zemni Plyn a Nafta 26, 665-688.

Krhovský, J., Adamová, J., Hladiková, J. \& Maslowská, H., 1992. Paleoenvironmental changes across the Eocene/ Oligocene boundary in the Ždánice and Pouzdřany units (western Carpathians, Czechoslovakia): the long-term trend and orbitality forced changes in nannofossils assemblages. Knihovnièka ZPN (Zemni Plyn a Nafta) 14b, 105-187.

KsiążKIEwicz, M. 1975. Bathymetry of the Carpathian Flysch Basin. Acta Geologica Polonica 25, 309-367.

Leriche, M. 1908. Sur un appareil fanonculaire de Cetorhinus trouvé à l'état fossile dans le Pliocène d'Anvers. Comptes Rendus Hebdomadaires des Séances de l'Academie des Sciences 146, 875-878.
Lin, C.-H., Girone, A. \& Nolf, D. 2016. Fish otolith assemblages from Recent NE Atlantic sea bottoms: A comparative study of palaeoecology. Palaeogeography, Palaeoclimatology, Palaeoecology 446, 98-107.

DOI 10.1016/j.palaeo.2016.01.022

Lowe, R.T. 1841. Certain new species of Madeiran fishes. Proceedings of the Zoological Society of London 8, 36-39.

Martini, E. 1971. Standard Tertiary and Quaternary calcareous nannoplankton zonation, 739-785. In FARINACCI, A. (ed.) Proceedings of the II. Planktonic Conference, Roma 1970, volume 2. Tecnoscienza, Rome.

Maxwell, E.E., Alexander, S., Bechly, G., Eck, K., Frey, E., Grimm, K., Kovar-Eder, J., Mayr, G., Micklich, N., Rasser, M., Roth-Nebelsick, A., Salvador, R.B., Schoch, R.R., Schweigert, G., Stinnesbeck, W., Wolf-Schwenninger, K. \& ZiegleR, R. 2016. The Rauenberg fossil Lagerstätte (Baden-Württemberg, Germany): a window into early Oligocene marine and coastal ecosystems of Central Europe. Palaeogeography, Palaeoclimatology, Palaeoecology 463, 238-260. DOI 10.1016/j.palaeo.2016.10.002

Melinte-Dobrinescu, M. \& Brustur T. 2008. Oligocene-Lower Miocene events in Romania. Acta Palaeontologica Romanie 6, 203-215.

Meulenkamp, J.E., Sissingh, W., Londeix, L., Chahuzac, B., Calvo, J.P., Daams, R., Studencka, B., Kováč, M., Nagymarosy, A., Rusu, A., Badescu, D., Popov, S.V., Scherba, I.G., Roger, J., Platel, J.P., Hirsch, F., Sadek, A., Abdel-Gawad, G.I., Yaich, C., Ben Ismail-Lattrache, K. \& Bouaziz, S. 2000. Late Rupelian (32-29 Ma), 171-178. In Dercourt, J., Gaetani, M., Vrielynck, B., Barrier, E., Biju-Duval, B., Brunet, M.F., Cadet, J.P., Crasquin, S. \& Sandulescu, M. (eds) Peri-Tethys Atlas, Paleogeographic Maps with Explanatory Notes. CCGM/CGMW, Paris.

MickLich, N. 1998. New information on the fish fauna of the Frauenweiler fossil site. Italian Journal of Zoology (Supplement) 65, 169-184.

DOI 10.1080/11250009809386809

Micklich, N. \& Hildebrandt, L.H. 2010. Emergency excavation in the Grube Unterfeld (Frauenweiler) clay pit (Oligocene, Rupelian; Baden-Württemberg, S Germany): new records and palaeoenvironmental information. Kaupia 17, 3-21.

Micklich, N. \& PArin, N.N. 1996. The fishfauna of Frauenweiler (Lower Oligocene, Rupelian; Germany): preliminary results of a review. Instituto Espanol de Oceanografia, Publicaciones Especiales 21, 129-148.

Monsch, K.A. \& Bannikov, A.F. 2012. New taxonomic synopses and revision of the scombroid fishes (Scombroidei, Perciformes), including billfishes, from the Cenozoic of territories of the former USSR. Earth and Environmental Science Transactions of the Royal Society of Edinburgh 102, 253-300. DOI 10.1017/S1755691011010085

Monsch, K.A. \& Micklich, N. 2018. Catalogue of the Scombroid Fishes from the Grube Unterfeld ("Frauenweiler") Fossil Site at Rauenberg (Baden-Württemberg, S. Germany). Kaupia 22, 7-154.

Møller, P.R., Knudsen, S.W., Schwarzhans, W. \& Nielsen, J.G. 2016. A new classification of viviparous brotulas 
(Bythitidae)-with family status for Dinematichthyidae-based on molecular, morphological and fossil data. Molecular Phylogenetics and Evolution 100, 391-408.

DOI 10.1016/j.ympev.2016.04.008

MüLlER, J. 1845. Über den Bau und die Grenzen der Ganoiden und über das natürlichen System der Fische. Abhandlungen Akademie der Wissenschaften, Berlin 1844, 117-216.

Nafpaktitis, B.G. 1984. Myctophidae, 1-8. In Fischer, W. \& Bianchi, G. (eds) FAO Species Identification Sheets for Fishery Purposes, Western Indian Ocean, Vol. III. FAO, Rome.

Nolf, D. \& Brzobohaty, R. 1994. Fish otoliths from the Late Oligocene (Eger and Kiscell Formations) in the Eger area (northeastern Hungary). Bulletin van het Koninklijk Belgisch Instituut voor Natuurwetenschappen. Aardwetenschappen = Bulletin de l'Institut Royal des Sciences Naturelles de Belgique. Sciences de la Terre 64, 225-252.

OlszewsKa, B. 1985. Foraminifera from the Menilite beds of Polish Outer Carpathians. Annales Societatis Geologorum Poloniae 55, 201-250.

Olszewska, B. \& SzydŁo, A. 2017. Environmental stress in the northern Tethys during the Paleogene: a review of foraminiferal and geochemical records from the Polish Outer Carpathians. Geological Quarterly 61, 682-696. DOI 10.7306/gq.1369

Parin, N.V. \& NAKAmURA, I. 2002. Trichiuridae, 1375-2127. In Carpenter, K.E. (ed.) The living marine resources of the Western Central Atlantic. Volume 3: Bony fishes part 2 (Opistognathidae to Molidae), sea turtles and marine mammals. FAO Species Identification Guide for Fishery Purposes and American Society of Ichthyologists and Herpetologists Special Publication No. 5. FAO, Rome.

PaucĂ, M. 1929. Vorläufige Mitteilung uber eine fossile Fischfauna aus den Oligozanschiefern von Suslanesti. Bulletin de la Section Scientifique Academie Roumaine 12, 112-120.

PAUCĂ, M. 1931 Zwei Fischfaunen aus den oligozäenen Menilitschiefern von Mähren. Annalen des Naturhistorischen Museums in Wien 46, 147-152.

PauCĂ, M. 1934. Die fossile Fauna und Flora aus dem Oligozan von Suslanesti-Muscel in Rumania. Anuarul Instiutului Geologic al Romaniei 16, 575-668.

Pharisat, A. 1991. La paléoichthyofaune du Rupélien marin de Froidefontaine (Territoire de Belfort). Annales Scientifiques de l'Université Franche-Comté Besançon, Géologie 4, 13-97.

Pharisat, A. \& Micklich, N. 1998. Oligocene fishes in the western Paratethys of the Rhine Valley Rift System. Italian Journal of Zoology (Supplement) 65, 163-168. DOI 10.1080/11250009809386808

Popov, S.V., Akhmetiev, M.A., Burgova, E.M., Lopatin, A.V., Amitrov, O.V., Andreyeva-Grigorovich, A.S., Zaporozhec, N.I., Zherikhin, V.V., Krasheninnikov, V.A., Nikolaeva, I.A., SytcheVsKayA, E.K. \& ScherbA, I.B. 2002. Biogeography of the Northern Peri-Tethys from the Late Eocene to the Early Miocene, Part 2: Early Oligocene. Paleontological Journal (Supplement) 36, S185-S259.

PřIKRYL, T. 2013. An annotated list of the Oligocene fish fauna from the Osíčko locality (Menilitic Fm.; Moravia, the Czech
Republic). Acta Musei Nationalis Pragae, Series B, Historia Naturalis 69, 195-203. DOI 10.14446/AMNP.2013.195

Přikryl, T. \& Carnevale, G. 2017. An Oligocene toadfish (Teleostei, Percomorpha) from Moravia, Czech Republic: The earliest skeletal record for the order Batrachoidiformes. Bulletin of Geosciences 92, 123-131.

DOI 10.3140/bull.geosci.1662

Přikryl, T. \& Carnevale, G. 2018. Ophidiiform fishes from the Oligocene-early Miocene of Moravia, Czech Republic. Bulletin of Geosciences 93, 477-489.

DOI 10.3140/bull.geosci.1724

PřIrryl, T., Prokofiev, A.M. \& Krzemiński, W. 2012. Feeding habits of the Oligocene bristlemouth fish Scopeloides glarisianus (Teleostei: Stomiiformes: Gonostomatidae). Geobios 45, 377-386. DOI 10.1016/j.geobios.2011.10.012

PřIKryl, T., Kania, I. \& Krzemiński, W. 2016. Synopsis of fossil fish fauna from the Hermanowa locality (Rupelian; Central Paratethys; Poland): current state of knowledge. Swiss Journal of Geosciences 38, 429-443.

DOI 10.1007/s00015-016-0216-5

Přikryl, T., Schwarzhans, W. \& Kovalchuk, O. 2017. Lanternfishes (Myctophidae) with otoliths in situ from the Early Oligocene of the Eastern Paratethys (western Ukraine). Neues Jahrbuch für Geologie und Paläontologie, Abhandlungen 285, 213-225. DOI 10.1127/njgpa/2017/0678

Prokofiev, A.M. 2002. The Phosichthyidae (Pisces: Stomiiformes) from the Eocene-Miocene of Russia and Adjacent Areas. Paleontologicheskii Zhurnal 5, 70-82 [Paleontological Journal 5, 512-524 (2002a)].

Prokofiev, A.M. 2005a. Revision of Protacanthopterygii (Osteichthyes: Euteleostei) from Cenozoic marine deposits of the Caucasus and Turkmenistan: I. The orders Argentiniformes and Salmoniformes s.str. (sensu Johnson, Patterson, 1996) in the Oligocene-Miocene of the Caucasus. Journal of Ichthyology 45, 5-20.

Prokofiev, A.M. 2005b. Systematics and phylogeny of the stomiiform fishes (Neoteleostei: Stomiiformes) from the Paleogene-Neogene of Russia and adjacent regions. Journal of Ichthyology (Supplement) 45, S89-S162.

Prokofiev, A.M. 2006. Fossil Myctophoid fishes (Myctophiformes: Myctophoidei) from Russia and adjacent regions. Journal of Ichthyology (Supplement) 46, 38-83. DOI 10.1134/S0032945206100043

Prokofiev, A.M. 2007. Meso- and bathypelagic fishes of the orders Stomiiformes and Myctophiformes in the PaleogeneNeogene of Russia and adjacent regions, 49-62. In Rozanov, A.Yu. et al. (eds) Sovremennaya Paleontologiya: Klassicheskie i Noveishie Metody [Modern Paleontology: Classical and New Methods] 2007. Paleontological Institute RAN, Moscow, Russia. [in Russian]

RAFINESQUE, C.S. 1810. Caratteri di alcuni nuovi generi e nuove specie di animali e piante della Sicilia, con varie osservazioni sopra i medisimi, 1.69 pp. Sanfilippo, Palermo.

DOI 10.5962/bhl.title.104418

RATH, G. von 1859. Beiträge zur Kenntniss der fossilen Fische des Plattenberges im Canton Glarus. Zeitschrift der Deutschen Geologischen Gesellschaft 11, 108-132. 
Regan, C.T. 1911. The Anatomy and Classification of the Teleostean Fishes of the Order Iniomi. Annals and Magazine of Natural History (Series 8) 7, 120-133.

DOI 10.1080/00222931108692913

Reinecke, T., Stapf, H. \& Raisch, M. 2001. Die Selachier und Chimären des Unteren Meeressandes und Schleichsandes im Mainzer Becken (Alzey- und Stadecken-Formation, Rupelium, Unteres Oligozän). Palaeontos 1, 1-73.

RögL, F. 1998. Palaeogeographic considerations for Mediterranean and Paratethys sea ways (Oligocene to Miocene). Annalen des Naturhistorischen Museums in Wien 99A, 279-310.

RöGL, F. 1999. Mediterranean and Paratethys palaeogeography during the Oligocene and Miocene, 8-22. In Agusti, J., Rook, L. \& Andrews, P. (eds) Hominoid Evolution and Climatic Change in Europe, The Evolution of Neogene Terrestrial Ecosystems in Europe. Cambridge University Press, Cambridge, U.K. DOI 10.1017/CBO9780511542329.002

Rusu, A. 1977. La stratigraphie des dépots oligocènes du nordouest de la Transylvanie (la région de Treznea Hida-Poiana Blenchii. Anuarul Institutului de Geologie si Geofizică 51, 69-224.

Rusu, A. 1988. Oligocene events in Transilvania (Romania) and the first separation of Paratethys. Dâri de Seamâ ale Sedintelor. 5 Tectonica i Geologie regionala 72-73, 207-223.

Sachsenhofer, R.F., Popov, S.V., Coric, S., Mayer, J., Misch, D., Morton, M.T., Pupp, M., Rauball, A. \& Tari, G. 2018. Paratethyan petroleum source rocks: an overview. Journal of Petroleum Geology 41, 219-246. DOI 10.1111/jpg.12702

Sachsenhofer, R.F., Popov, S.V. Bechtel, A., Coric, S., Francu, J., Gratzer, R., Grunert, P., Kotarba, M., Mayer, J., Pupp, M., Rupprecht, B.J. \& Vincent, S.J. 2017. Oligocene and Lower Miocene source rocks in the Paratethys: Palaeogeographic and stratigraphic controls, 267-306. In Simmons, M.D., TARI, G.C. \& OKay A.I. (eds) Petroleum Geology of the Black Sea. Geological Society London, Special Publication 464. DOI 10.1144/SP464.1

Schulz, H.-M., Bechtel, A., Rainer, T., Sachsenhofer, R.F. \& Struck, U. 2004. Paleoceanography of the western Central Paratethys during Early Oligocene nannoplankton Zone NP23 in the Austrian Molasse Basin. Geologica Carpathica 55, 311-323.

Schulz, H.-M., Bechtel, A. \& Sachsenhofer, R.F. 2005. The birth of the Paratethys during the early Oligocene: from Tethys to an ancient Black Sea analogue? Global and Planetary Change 49, 163-176. DOI 10.1016/j.gloplacha.2005.07.001

Siemińska, A., Starzec, K., Waśkowska, A. \& Wendorff, M.
2020. Sedimentary and diapiric mélanges in the Skrzydlna area (Outer Carpathians of Poland) as indicators of basinal and structural evolution. Journal of the Geological Society 177, 600-618. DOI 10.1144/jgs2019-045

Steininger, F.F. \& Wessely, G. 2000. From the Tethyan Ocean to the Paratethys Sea: Oligocene to Neogene Stratigraphy, Paleogeography and Paleobiogeography of the circumMediterranean region and the Oligocene to Neogene Basin evolution in Austria. Mitteilungen der Österreichischen Geologischen Gesellschaft 92, 95-116.

Studencka, B., Popov, S.V, Bieńkowska-Wasiluk, M. \& Wasiluk, R. 2016. Oligocene bivalve faunas from Silesian Nappe, Polish Outer Carpathians: evidence of the early history of the Paratethys. Geological Quarterly 60, 317-340. DOI 10.7306/gq.1296

Suchocka, A., Barski, M. \& Bieńkowska-Wasiluk, M. 2019. Dinoflagellate cyst stratigraphy of the Popiele Member and Menilite Formation from the Boryslav-Pokuttya Nappe (Aksmanice, SE Poland). Geological Quarterly 63, 539-557.

SzydŁo, A., Garecka, M., Jankowski, L. \& Malata, T. 2014. Paleogene microfossils from the submarine debris flows in the Skole Basin (Polish and Ukraine Outer Carpathians). Geology, Geophysics and Environment 40, 49-65. DOI 10.7494/geol.2014.40.1.49

SzymczyK, W. 1978. Clupeid scales from the Menilite Beds (Palaeogene) of the Carpathians. Acta Palaeontologica Polonica 23, 387-407.

Weitzman, S.H. 1974. Osteology and evolutionary relationships of the Sternoptychidae, with a new classification of stomiatoid families. Bulletin of the American Museum of Natural History 153, 331-478.

Welton, B.J. 2013. A new archaic basking shark (Lamniformes: Cetorhinidae) from the Late Eocene of Western Oregon, U.S.A., and description of the dentition, gill rakers and vertebrae of the Recent basking shark Cetorhinus maximus (Gunnerus). New Mexico Museum of Natural History and Science, Bulletin 58, 1-48.

Wettstein, A. 1886. Über die Fischfauna des Tertiären Glarnerschiefers. Mémoires de la Société Paléontologique Suisse 13, 1-103.

White, W.T., Ebert, D.A, NaYlor, G.J.P., Ho, H.-C., Clerkin, P.J., Veríssimo, A. \& Cotton, C.F. 2013. Revision of the genus Centrophorus (Squaliformes: Centrophoridae): Part 1 Redescription of Centrophorus granulosus (Bloch \& Schneider), a senior synonym of $C$. acus Garman and C. niaukang Teng. Zootaxa 3752, 35-72. DOI 10.11646/zootaxa.3752.1.5

\section{Electronic Appendix}

Appendix 1. Studied specimens from the Outer Carpathians and its localities.

Appendix 2. List of fish fauna of the Dynów Marl Member of the Menilite Formation in Poland.

Appendix 3. Stratigraphic occurrence of the taxa identified in this investigation in the Dynów Marl Member (Outer Carpathians, Poland). Abbreviation: $x$ - presence in indicated period (Fedotov \& Bannikov 1989, Brzbohatý \& Nolf 1995, Prokofiev 2005b, Kotlarczyk et al. 2006, Kriwet \& Klug 2009, Monsch \& Bannikov 2012, Welton 2013, Cappetta et al. 2016, Gradianu et al. 2017, Schwarzhans \& Stringer 2020). 